Article

\title{
Which Residential Clusters of Walkability Affect Future Population from the Perspective of Real Estate Prices in the Osaka Metropolitan Area?
}

\author{
Haruka Kato *DiD and Atsushi Takizawa $(D$ \\ Department of Housing and Environmental Design, Graduate School of Human Life Science, \\ Osaka City University, Osaka 5588585, Japan; takizawa@osaka-cu.ac.jp \\ * Correspondence: haruka-kato@osaka-cu.ac.jp; Tel.: +81-6-6605-2823
}

check for

updates

Citation: Kato, H.; Takizawa, A. Which Residential Clusters of Walkability Affect Future Population from the Perspective of Real Estate Prices in the Osaka Metropolitan Area? Sustainability 2021, 13, 13413. https://doi.org/10.3390/su132313413

Academic Editors: Elisa Conticelli,

Paulo Ribeiro, George N

Papageorgiou and Fernando Fonseca

Received: 4 October 2021

Accepted: 1 December 2021

Published: 3 December 2021

Publisher's Note: MDPI stays neutral with regard to jurisdictional claims in published maps and institutional affiliations.

Copyright: (c) 2021 by the authors. Licensee MDPI, Basel, Switzerland. This article is an open access article distributed under the terms and conditions of the Creative Commons Attribution (CC BY) license (https:// creativecommons.org/licenses/by/ $4.0 /)$.

\begin{abstract}
In Japan, where the population is declining and aging significantly, walkability has attracted attention as a way to improve residents' lifestyles. Therefore, it is essential to identify the residential clusters where walkability improvement would contribute to the maintenance of the population in order to select urban areas for the implementation of walkable designs. This study aimed to identify the residential clusters in which walkability affects the future population from the perspective of real estate prices. The reason for focusing on real estate prices is that they are expected to be a confounding factor connecting walkability and the future population. The method we used was to analyze the structural equation modeling of the impact of walkability index, real estate prices, and future population change ratio. This analysis was based on the neighborhood association scale. This study clarified that effective residential clusters are the business center cluster and the sprawl cluster. In the business center cluster and the sprawl cluster, the price of apartments for sale is the real estate value, through which the walkability index positively impacts the future population change ratio. This means that it is expected to contribute to the maintenance of the future population through a combination of walkable designs and housing policies that encourage people to change their residence types to apartments for sale when rebuilding old building stock using the location optimization plan policy.
\end{abstract}

Keywords: walkability; population decline; real estate prices; Osaka metropolitan area; business center cluster; sprawl cluster

\section{Introduction \\ 1.1. Background}

In Japan, the mission for urban planning is to support the country's declining population. A characteristic of Japan's declining population is the aging of the population [1]. Therefore, it is necessary for urban planning to enable older adults to continue to live healthily while the population declines. In this context, walkability has attracted attention in terms of sustaining the lifestyle of citizens, including older adults. Walkability is defined as a property of a residential environment that promotes walking or cycling with safety, comfort, and easy access to the attractions of daily life [2]. Improving walkability is expected to contribute to the health of residents [3,4] and their ecological footprint [5]. This means that designing walkable neighborhoods might help prevent rapid population decline. In Japan, the Location Optimization Plan has developed urban planning in preparation for a declining population since 2015 [6]. Since 2019, walkability has begun to attract attention because urban policies related to walkability are being developed. Kato [7] and Kato et al. [8,9] clarified that the COVID-19 (Coronavirus Disease 2019) pandemic accelerated the need for walkable neighborhoods in the Osaka metropolitan area. Therefore, it is essential to understand the impact of walkability on future populations, as this will enable us to take a practical approach to future urban planning. 
However, improving walkability will not be effective in all residential clusters. That is because the type of residential cluster influences the process of population decline. For example, Kato [10] clarified that the location of medical and welfare facilities influences the population level in the sprawl cluster, whereas the location of station buildings influences the population in the old New-Town cluster (old NT cluster). The old NT cluster was defined to be planned and large-scale suburban residential areas featuring detached houses for high-income workers, where located in hillside areas [10]. Therefore, it is essential to identify the residential clusters where walkability improvement would contribute to the maintenance of population in order to select urban areas for the implementation of walkable designs. In addition, if we can identify residential clusters where increased walkability does not contribute to maintaining the population, we can consider methods other than walkable designs. Therefore, this research hypothesis is that the relationship between walkability and future population could be clarified by analyzing real estate prices as a factor connecting.

\subsection{Purpose}

This study aimed to clarify the residential clusters in which walkability affects the future population from the perspective of real estate prices in the Osaka metropolitan area. The results would be worth it for urban planners to develop policies to prevent a rapid population decline. The reason for focusing on real estate prices is that they are expected to be a confounding factor connecting walkability and future population levels. Specifically, the precise impact of walkability on the future population has not been found. However, some research papers have reported on the relationship between walkability and real estate prices and the relationship between real estate prices and population. Therefore, this study attempts to analyze the impact of walkability, real estate prices, and future population through structural equation modeling (SEM). The SEM allows us to clarify the impact of walkability on the future population. By analyzing the SEM for each residential cluster, effective residential clusters can be clarified.

In this study, we analyzed the Osaka metropolitan area. We used this area because the population of the Osaka metropolitan area has been declining on a metropolitan scale [11]. The analysis scale was the neighborhood association (NA) scale. In Japan, NA is almost the same as the zip code. The NA scale is the smallest scale of community governance identified by the Local Autonomy Act in Japan [12]. Therefore, NA has played an essential role in reaching a consensus on community welfare. Thus, we decided that the NA scale fits the purpose of this analysis.

\subsection{Literature Review}

The novelty of this study is its analysis of the impact of walkability on the future population in relation to the type of residential cluster involved. The relationship between walkability and real estate prices has been studied previously. Renne et al. [13] determined that areas with a high walkability have higher real estate prices in 4399 locations in the United States. Similarly, Xia et al. [14] also clarified that housing price and walkability are statistically significantly positively correlated in Nanjing by developing a walkability measure model. However, Zhang et al. [15] found that walkability and real estate price are negatively correlated in the Futian District in the central area of Shenzhen. These results suggest that the statistical relationship between walkability and real estate price changes according to the type of residential cluster involved.

Furthermore, this relationship is influenced not only by the residential cluster but also by the real estate type. Regarding detached houses such as single-family homes, Boyle et al. [16] found that the impact of walkability on housing prices was not statistically significant in Miami. However, Li et al. [17] determined that walkability was positively correlated with housing prices in areas with high walkability in Austin. On the other hand, it was also found that walkability and housing price are not correlated in areas where people tend to use automobiles. These results verify that the residential cluster 
involved influences the statistical relationship. Regarding apartments, Kim [18] found that walkability and house price were positively correlated in areas with low housing prices in Seoul. In contrast, it was also found that there was no statistical relationship in areas with high housing prices. Based on this research, the novelty of this study is its attempt to clarify the statistical relationship according to the type of residence cluster and property type involved.

The relationship between real estate prices and population has been studied in prior research. Saita et al. [19] clarified that real estate prices are positively correlated with the total level of population in Japan and the United States. It was also found that real estate prices are negatively correlated with the old age dependency ratio. Moreover, in German metropolitan areas, Maennig et al. [20] determined that growth in terms of the population had no significant effect on the price of detached houses, whereas declining population significantly lowered prices. This result suggests that declining real estate prices might become a serious problem in Japan with its aging and shrinking cities. On the other hand, the population decline caused by rising real estate prices has also become a social problem known as gentrification [21]. For example, in Kyoto, an excessive increase in the number of simple accommodations has caused residents and stores to be displaced due to the rising land prices in a process of tourism gentrification [22]. Based on this research, the novelty of this study is to clarify the statistical relationship between walkability, real estate price, and the future population according to the type of residence cluster involved.

\subsection{Article Structure}

This manuscript consists of five chapters based on an IMRAD format: materials and methods in Section 2; results in Section 3; discussion in Section 4; and conclusions in Section 5 .

\section{Materials and Methods}

The analytical flow is summarized in Figure 1. The analysis method used was SEM based on the NA scale. The walkability index was used to calculate how pedestrian-friendly the urban environment is. Real estate prices were calculated using the At Home dataset. The future population change ratio was calculated using the cohort component method. Urban ecology analysis was used to classify residential clusters. Using the walkability index, real estate price, and future population change ratio, according to the residential cluster involved, an SEM in which walkability affects the real estate price and the real estate price affects the future population was analyzed.

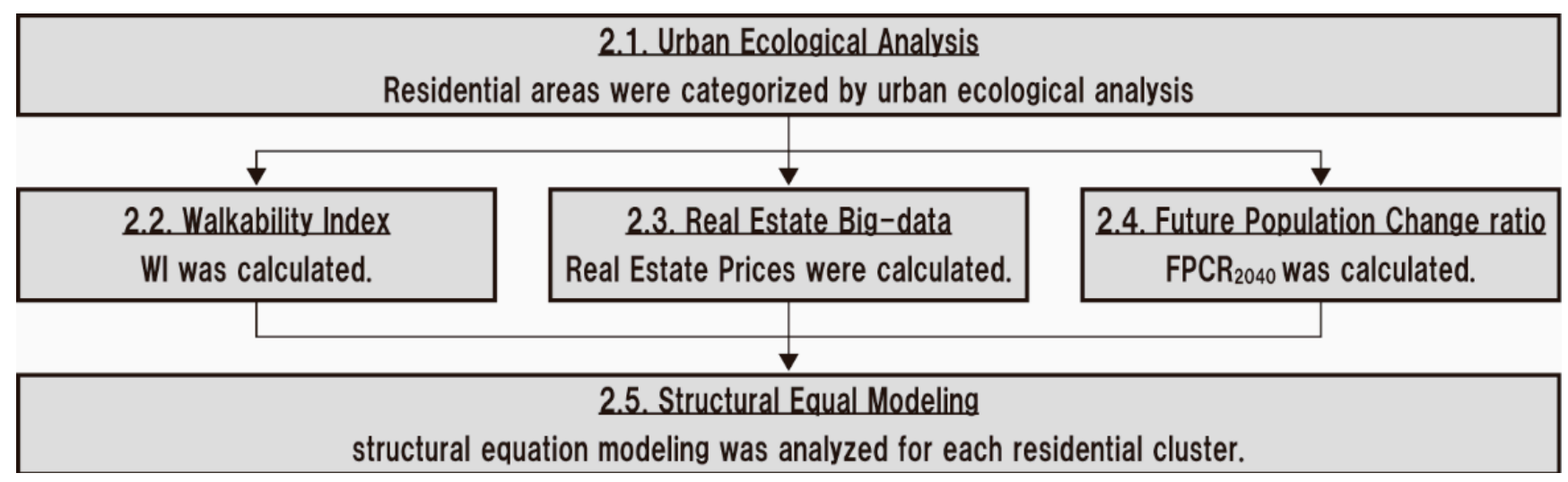

Figure 1. Analysis process used for each section.

\subsection{Urban Ecological Analysis}

Using urban ecological analysis, this study clarified the types of residential clusters present in the Osaka metropolitan area. This analysis was based on the NA scale. Urban ecological analysis analyzes geospatial patterns using an inductive method that makes use 
of statistical data [23]. Kato et al. [2] evaluated the effectiveness of urban ecological analysis in the Osaka metropolitan area. Moreover, Kato [5] analyzed the types of clusters present using urban ecological analysis in the Osaka metropolitan area, which is the same region and data as that studied in this paper. The validity of the analysis was also assessed $[8,10]$. The analysis consisted of five steps as detailed in Appendix A. The locations of those residential clusters are classified into three categories. The central areas are the inner city and business center clusters. Suburban areas include dense, public housing, non-residential, sprawl, high-rise residential, old NT, and suburban agriculture clusters. Rural areas include mining industry, agriculture, mountain, and rural clusters. For each of the clusters, this study analyzed the SEM.

\subsection{Walkability Index}

Using the walkability index, each NA was evaluated. Brownson et al. [24] classified three types of walkability indicators that use GIS-based measures, perceived environment measures, and observational measures. Walkability indicators that use GIS-based measures include the Walkability 3Ds [25], the Walk Score ${ }^{\circledR}$ [26], and the walkability index [27,28]. The Walk Score ${ }^{\circledR}$ was developed as an indicator for evaluating the walkability of neighborhood environments [22]. Koohsari et al. [29] validified the effectiveness of Walk Score ${ }^{\circledR}$ in Japan.

The walkability index is an evaluation index that was developed by Frank et al. $[27,28]$ as an index for evaluating the neighborhood environment in the United States. Many studies have verified the effectiveness of the walkability index using the number of pedestrians [30]. The walkability index includes three components. These are the net residential density (ND) in Equation (1), the density of street connectivity (SC) in Equation (2), and the land use mix (LUM) in Equation (3). WI, which is the score of the walkability index: the sum of the standardized values of ND, SC, and LUM in Equation (4). We followed the method of Kato [10], which analyzed the Osaka metropolitan area using the same data.

$$
\begin{gathered}
\mathrm{ND}_{k}=\frac{H_{k}}{A_{k}}, \\
\mathrm{SC}_{k}=\frac{I_{k}}{L_{k}}, \\
\mathrm{LUM}_{k}=\sum_{i=1}^{3} \frac{p_{k, i} \times \ln p_{k, i}}{\ln n}, \\
W I_{k}=z_{\_} \mathrm{ND}_{k}+z_{-} \mathrm{SC}_{k}+z_{-} \mathrm{LUM}_{k},
\end{gathered}
$$

where $H_{k}$ is the total number of net residents in the $\mathrm{NA}_{k}$ according to Japanese census data from 2015 [31]; $A_{k}$ is the total housing area in the $\mathrm{NA}_{k}$ according to Japanese census data from 2015 [31]; $I_{k}$ is the amount of street connectivity in the $\mathrm{NA}_{k}$ according to road centerline data [32]; $L_{k}$ is the total length of the street in the $\mathrm{NA}_{k}$ according to road centerline data [32] (m); $p_{k, i}$ is the area ratio of land use $i$ in the $\mathrm{NA}_{k}$ according to the data of the numerical map 5000 in Japan [33]; $i$ is the classification of land use $i$ (residential land, commercial land, public facility land); and $z_{-}$is the standardized value.

\subsection{Real Estate Big Data}

The housing prices of each NA were evaluated using the At Home dataset as real estate big data [34]. In particular, real estate and housing information were registered to the At Home Real Estate Information Network operated by At Home Co., Ltd., for five years from 2015 to 2019. The At Home Co., Ltd., is a company that provides real estate information services for real estate companies and consumers. More than 50,000 real estate companies use the dataset service throughout Japan, which is the largest number in Japan. At Home is a service that connects buyers and sellers of real estate in Japan. At Home Dataset is data on the prices offered by sellers. Based on the prices offered by sellers in this dataset, actual trades are conducted between individuals. There is little public disclosure of 
actual transaction prices between individuals in Japan. Therefore, the price of this dataset is an important indicator to estimate the transaction price.

This study categorized the real estate dataset into six types: apartments for sale, apartments for rent, detached houses for sale, detached houses for rent, shops for rent, and vacant lots for sale. These six types were selected as the main types of real estate traded in Japan. Shops are traded in the same way as houses and apartments. The dataset contained information on real estate price (rental fee/price), area, floor plan, structure, year of construction, location (zip code (postal code)), latitude/longitude), facilities, etc. Among these, detached houses do not include latitude/longitude data for reasons of personal privacy. Therefore, this study used the data of real estate price (rental fee/price), area, and zip code. Regarding the real estate price, rental fees were analyzed for apartments for rent, detached houses for rent, and stores for rent, and prices were analyzed for apartments for sale and detached houses for sale. This study did not include standard service fees in the real estate price (rental fee/price) because the fee varies depending on the lifestyle of each resident and owner. This study then calculated the real estate price per unit area $\left(\mathrm{Yen} / \mathrm{m}^{2}\right)$ for each zip code in the six categories of real estate. This study analyzed the data from the Osaka, Kyoto, and Hyogo prefectures.

\subsection{Future Population Change Ratio}

The future population change ratio between 2020 and $2040\left(\mathrm{FPCR}_{2040}\right)$ for each NA was calculated using the cohort component method with Japanese census data from 2015 [31]. We followed the method of Kato [10], which analyzed the Osaka metropolitan area using the same data. For the analysis of the cohort component method, this study used the "Future Population/Household Forecasting Program" (version 1.3) [35]. The program was developed by the National Institute for Land and Infrastructure Management in Japan. The cohort component method estimates the future population of each cohort by assuming the future values for two population change factors; these factors are the "ratio of women and children" and the "net movement ratio". This section analyzes the cohort component method. It is preferable to use the cohort component method in NA in areas where the past population experienced remarkable changes or where the past population change rate is unsuitable for estimating the future population.

Using the cohort component method, the $\mathrm{FPCR}_{2040}$ of each NA was calculated with Equation (5). Then, a boxplot diagram of the $\mathrm{FPCR}_{2040}$ of each residential cluster was analyzed. Using this boxplot diagram, the residential clusters with rapidly declining populations were clarified:

$$
\mathrm{FPCR}_{2040}=\frac{\mathrm{P}_{2040}-\mathrm{P}_{2020}}{\mathrm{P}_{2020}},
$$

where $P_{2040}$ is the population of 2040 based on the data of "Future Population/Household Forecasting Program [35]" and $\mathrm{P}_{2020}$ is the population of 2020 based on the data of "Future Population/Household Forecasting Program [35]".

\subsection{Structural Equation Modeling}

In this study, we analyzed the SEM, for each residential cluster, of the impact of walkability on real estate price and the impact of real estate price on $\mathrm{FPCR}_{2040}$. Specifically, for each zip code, we conducted a path analysis of the WI calculated in Section 2.2, the real estate price per unit area $\left(\mathrm{Yen} / \mathrm{m}^{2}\right)$ of real estate types calculated in Section 2.3, and the $\mathrm{FPCR}_{2040}$ calculated in Section 2.4. The real estate types are apartments for sale, apartments for rent, detached houses for sale, detached houses for rent, shops for rent, and vacant lots for sale. The SEM is shown in Figure 2. Based on the results of GFI (Goodness of Fit Index), AGFI (Adjusted Goodness of Fit Index), and RMSTA (Root-Mean-Square Error of Approximation), effective models of residential clusters were clarified. 


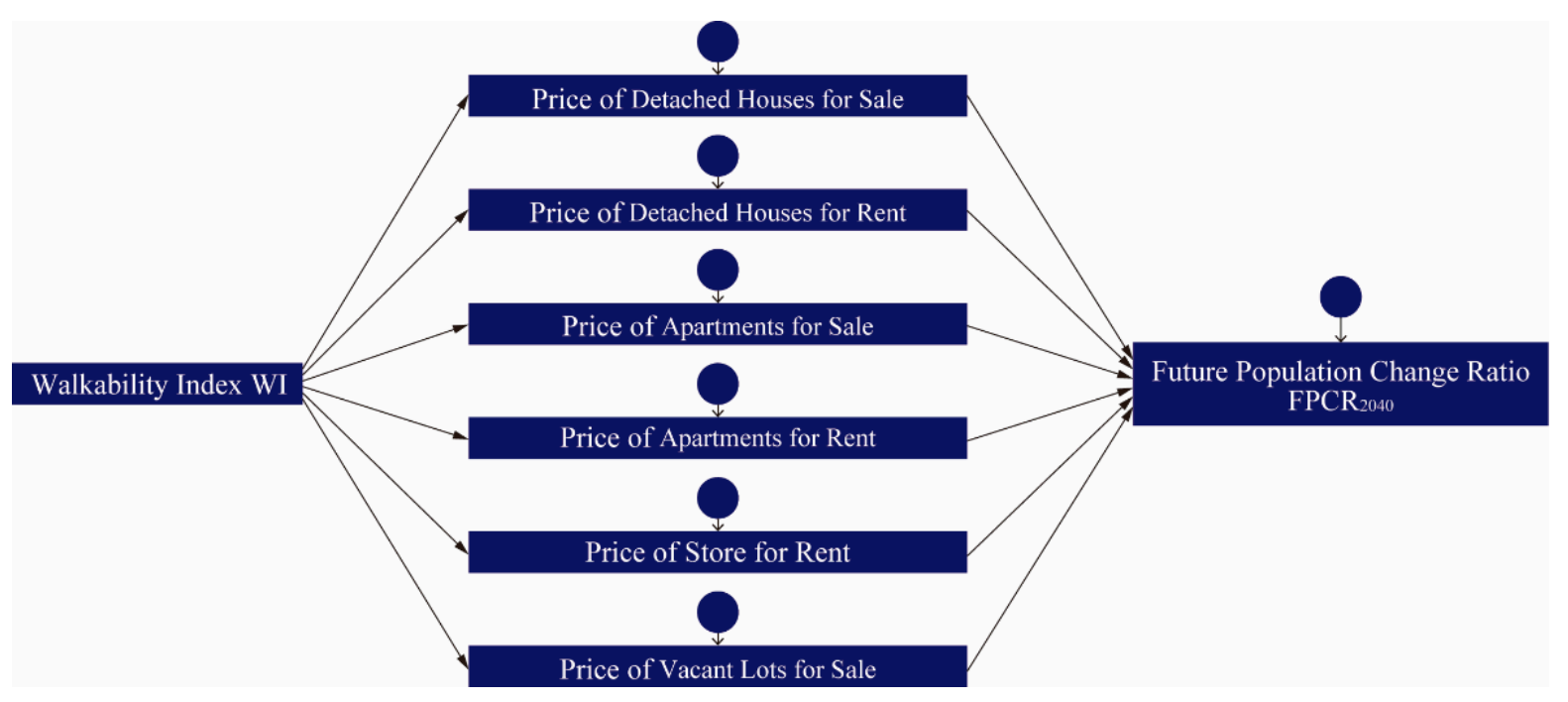

Figure 2. SEM of this study.

\section{Results}

\subsection{Map of Each Score}

Section 3.1 examines the distribution on the map. First, the results of the urban ecological analysis are shown in Figure 3. As a result, Figure 3 shows thirteen types of residential clusters. The thirteen clusters were named based on the type of residential area. The clusters were assessed by Kato $[5,10]$. The locations of these residential clusters are classified into three categories by the criteria of the urbanized area ratio (\%) and the average distance from the center $(\mathrm{km})$. Central areas include the inner city $(84.5 \%, 19.3 \mathrm{~km})$ and business center $(86.2 \%, 34.5 \mathrm{~km})$ clusters. Suburban areas include the dense $(77.1 \%, 31.2 \mathrm{~km})$, public housing $(72.4 \%, 26.7 \mathrm{~km})$, non-residential $(55.2 \%, 43.9 \mathrm{~km})$, sprawl $(66.2 \%, 38.2 \mathrm{~km})$, high-rise residential $(61.8 \%, 25.9 \mathrm{~km})$, old NT $(59.1 \%, 26.7 \mathrm{~km})$, and suburban agriculture $(21.3 \%, 63.1 \mathrm{~km})$ clusters. Rural areas include the mining industry $(45.1 \%, 59.9 \mathrm{~km})$, agriculture $(23.6 \%, 71.6 \mathrm{~km})$, mountain $(40.7 \%, 56.1 \mathrm{~km})$, and rural $(24.9 \%, 52.1 \mathrm{~km})$ clusters. The infrastructure typology of each residential cluster was also analyzed based on the average land use area $\left(\mathrm{m}^{2}\right)$. Rice field and farmland areas are large in the mining industry $\left(18,644 \mathrm{~m}^{2}\right)$, agriculture $\left(423,887 \mathrm{~m}^{2}\right)$, mountain $\left(24,012 \mathrm{~m}^{2}\right)$, suburban agriculture $\left(180,632 \mathrm{~m}^{2}\right)$, and rural $\left(81,475 \mathrm{~m}^{2}\right)$ clusters. The housing areas are large in the inner city $\left(47,374 \mathrm{~m}^{2}\right)$, dense $\left(46,892 \mathrm{~m}^{2}\right)$, public housing $\left(61,492 \mathrm{~m}^{2}\right)$, sprawl $\left(34,236 \mathrm{~m}^{2}\right)$, high-rise residential $\left(72,499 \mathrm{~m}^{2}\right)$, and old NT $\left(48,441 \mathrm{~m}^{2}\right)$ clusters.

Based on Appendix A, a population who works in agriculture and forestry is high in agriculture $(0.13 \%)$, suburban agriculture $(0.03 \%)$, and rural cluster $(0.03 \%)$. Besides, the population who work in the mining industry is high in the mining industry cluster $(0.09 \%)$. There are almost no residents in the non-residential cluster. The other clusters are populated by white-collar workers, such as those who work in the service industry and in education.

Next, the results for the walkability index of each NA are plotted in Figure 4. Figure 4 categorizes the data with seven levels of WI at 0.15 intervals. As a result, it was found that the WI is higher in urban areas. Moreover, in urban areas, it was also found that the WI was high along the train network. That is because urban areas have high walkability due to the concentration of urban facilities and population and to the presence of diverse land uses. That means that urban areas are easy to live within walking distance. Many people tend to walk and use public transportation. On the other hand, it was found that the WI was lower in bay areas and in mountainous areas. That is because bay areas and mountainous areas have low walkability due to the diffuse location of urban facilities and small population. That means that bay areas and mountainous areas are difficult to live in within walking distance. Many people tend to drive their cars. This result suggests that the location of the residential clusters might influence the WI score. 

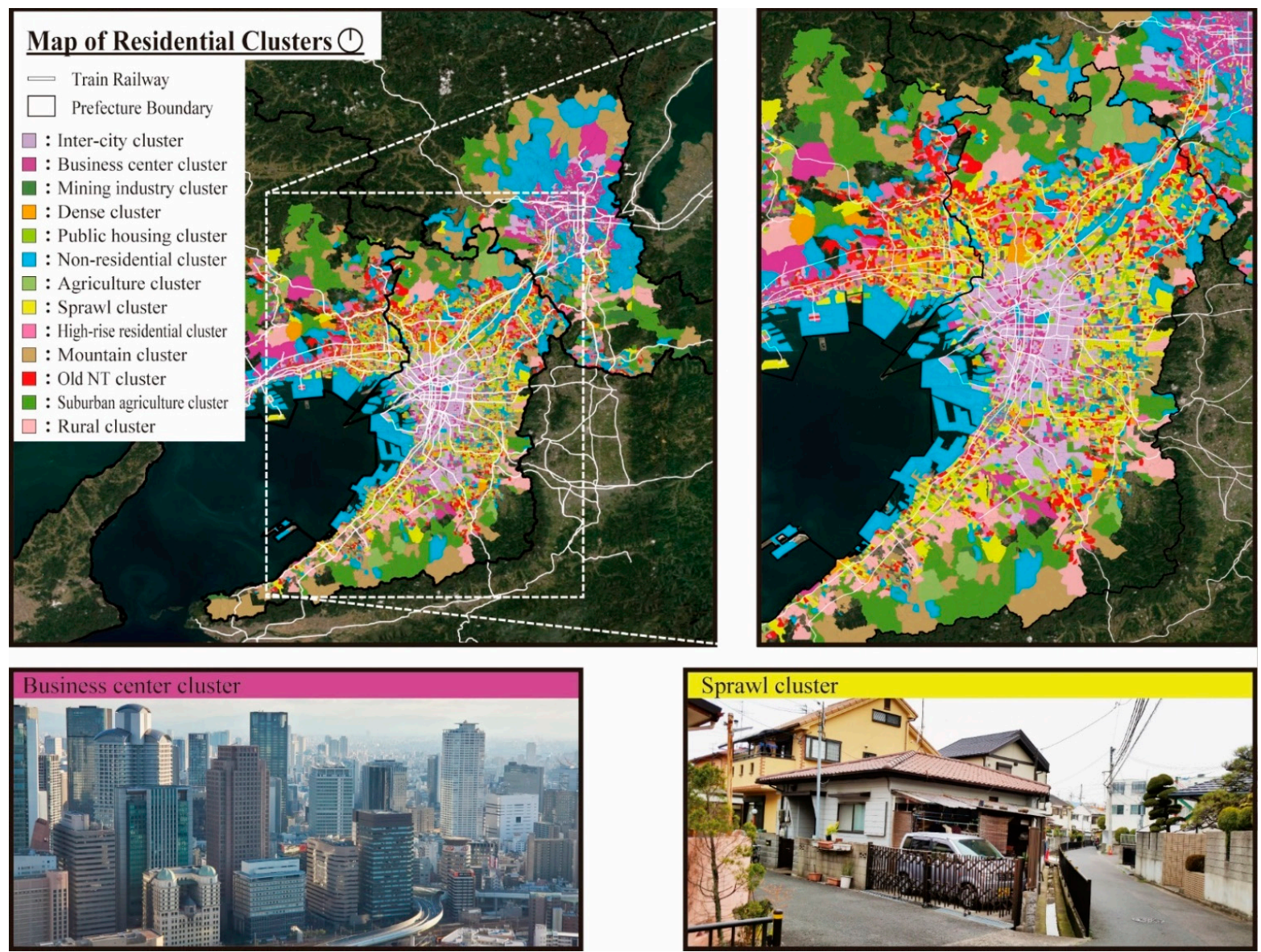

Figure 3. Map of residential clusters from the urban ecological analysis (Data Source: Kato [5,8,10]).
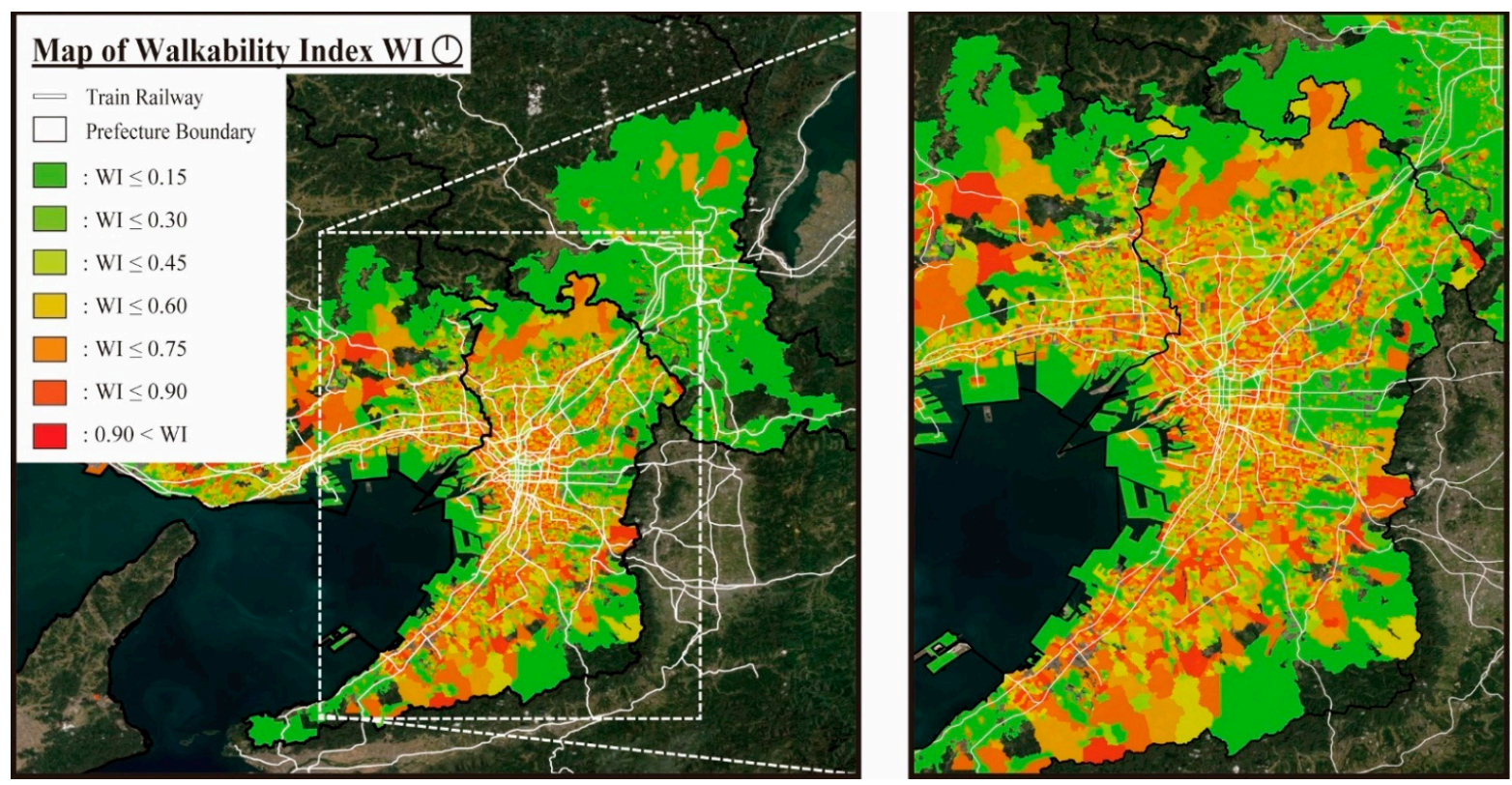

Figure 4. Map of WI (Data Source: Kato [5]).

The real estate data are plotted in Figure 5. First, the locations of various real estate types are shown in Figure 4. These types are apartments for sale, apartments for rent, detached houses for sale, detached houses for rent, shops for rent, and vacant lots for sale. As a result, Figure 4 shows that there are more apartments than detached houses and stores in this area. 
Among these types of real estate, Figure 4 also shows that apartments for rent are located widely across the Osaka metropolitan area. On the other hand, apartments for sale are mainly located in urban areas and areas with convenient transportation along railroad lines.
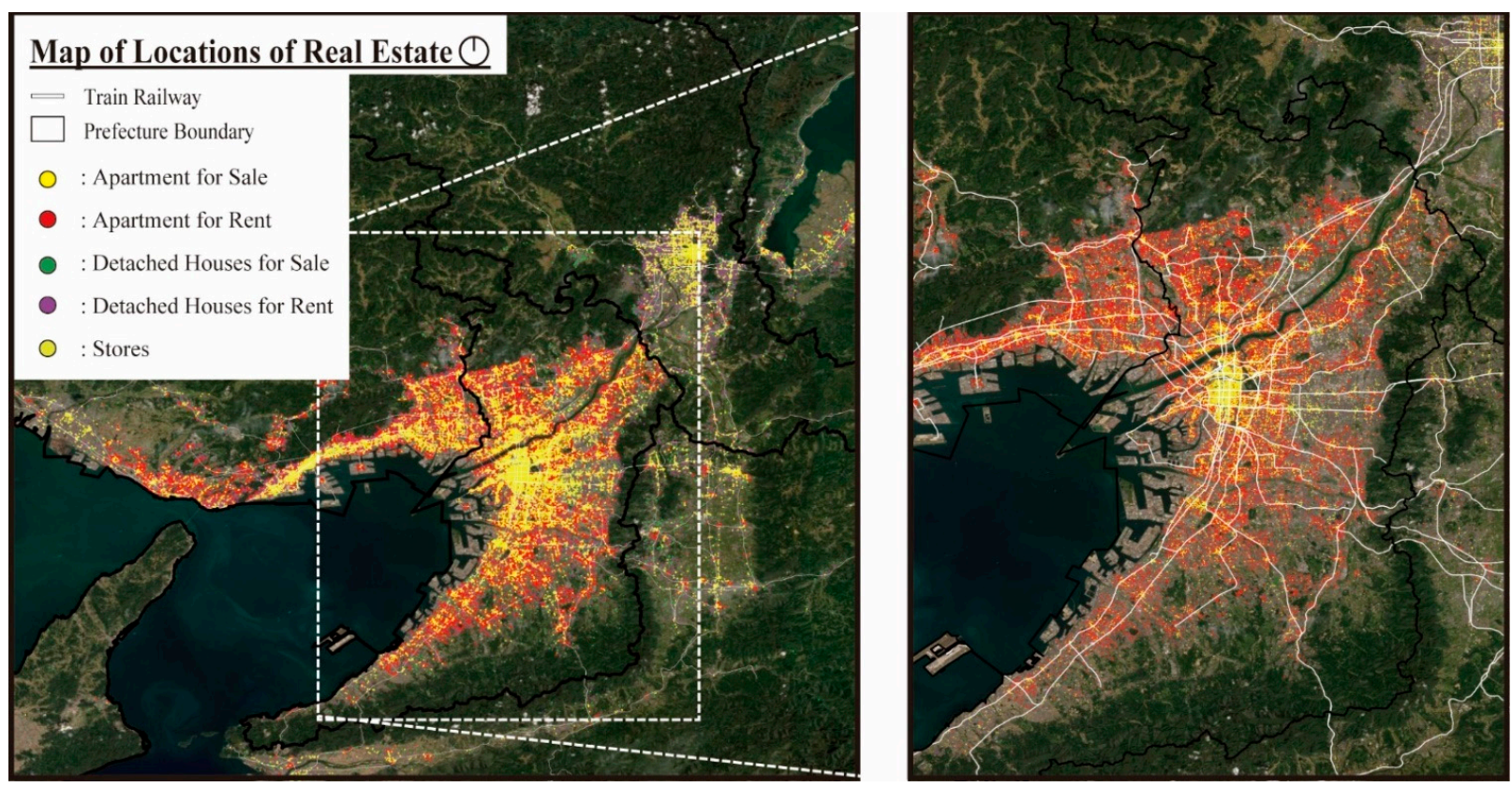

Figure 5. Map of the location of real estate (Data Source: Self-elaboration by the authors, 2021).

Next, Figure 6 shows the average price of an apartment according to the rent for each NA. The reason for analyzing apartments for rent was that they made up the majority of the six types of real estate. As a result, Figure 6 shows that apartments for rent were generally not located in mountainous areas. Moreover, it was found that the prices were higher in the central area of Osaka, Kyoto, and Kobe city. In addition, it was found that prices were higher in areas close to train railways. This result also suggests a relationship between real estate price and the location of residential clusters, such as WI in Figure 4.
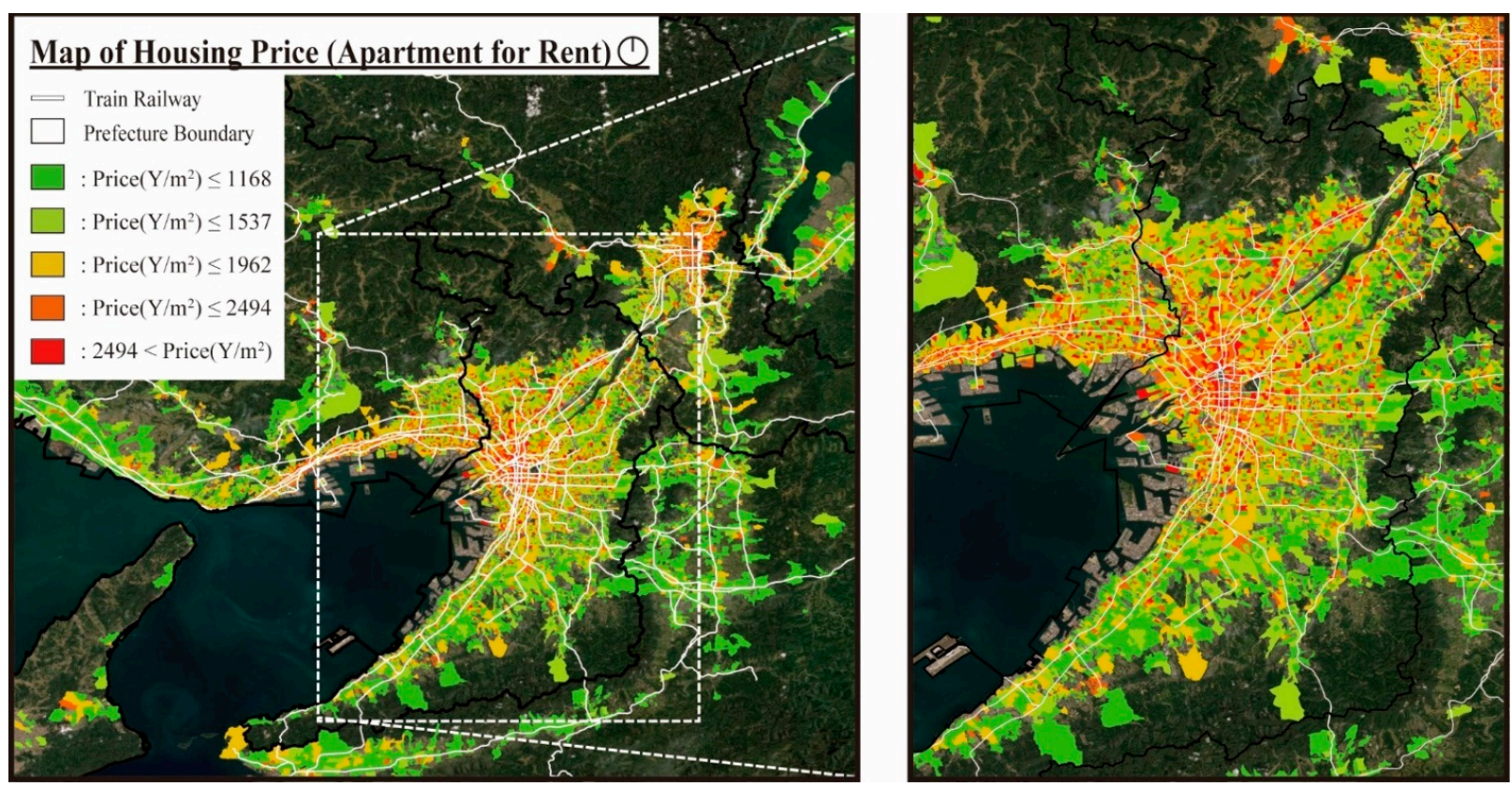

Figure 6. Map of housing prices (apartments for rent) (Data Source: Self-elaboration by the authors, 2021). 
Finally, the $\mathrm{FPCR}_{2040}$ of each NA is plotted in Figure 7. Figure 7 categorizes the data using the Jenks natural breaks classification. Figure 7 shows that the population decreases in many areas. However, it was found that the population will increase in dispersed areas. The dispersed location bears no relation to the central area.
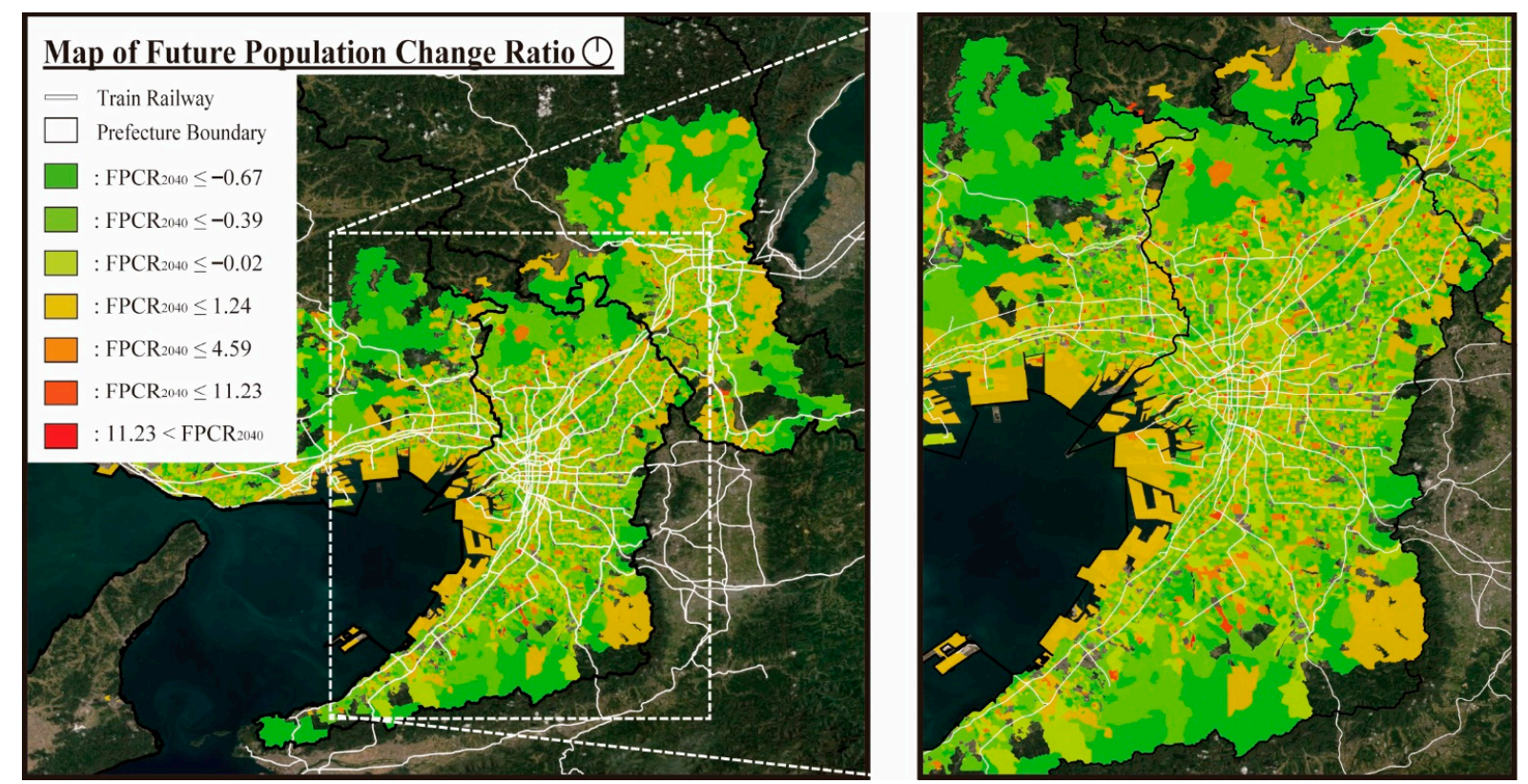

Figure 7. Map of future population change ratio $\mathrm{FPCR}_{2040}$ (Data Source: Kato [10]).

\subsection{Score of Residential Clusters}

Section 3.1 examines the scores for each residential cluster. The scores are WI, real estate price, and $\mathrm{FPCR}_{2040}$ and are analyzed in Section 3.1. First, the WI of each residential cluster was analyzed using a boxplot diagram in Figure 8. Figure 8 does not include plot outliers in the boxplot. Focusing on the median value, Figure 8 shows that that WI was higher in the inner city cluster $(\mathrm{WI}=0.60)$, the dense cluster $(\mathrm{WI}=0.61)$, the public housing cluster $(\mathrm{WI}=0.54)$, the sprawl cluster $(\mathrm{WI}=0.49)$, and the high-rise residential cluster $(\mathrm{WI}=0.46)$.

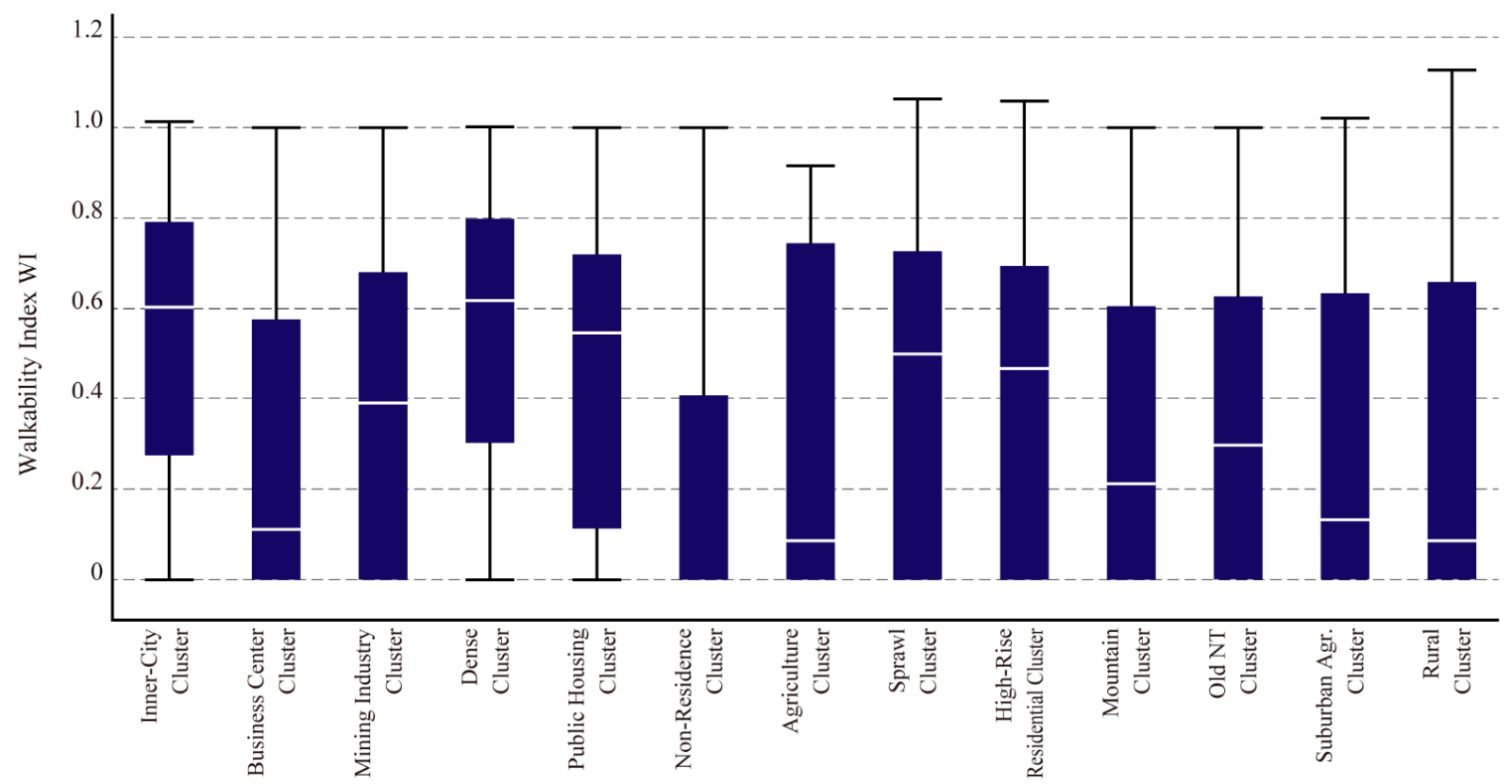

Figure 8. Box plot diagram of the WI of each residential cluster. 
Next, the amount of real estate available for each residential cluster is analyzed in Figure 9. Figure 9 shows that the inner city cluster has the highest amount of real estate available $(\mathrm{N}=2,221,702)$. The second-largest amount is the business center cluster $(\mathrm{N}=1,368,720)$. These clusters are both located in the city center. The following most significant clusters are residential clusters located in metropolitan suburban areas, such as sprawl clusters $(\mathrm{N}=1,008,296)$, dense urban clusters $(\mathrm{N}=661,647)$, old NT clusters $(\mathrm{N}=546,417)$, and public housing clusters $(\mathrm{N}=371,159)$.

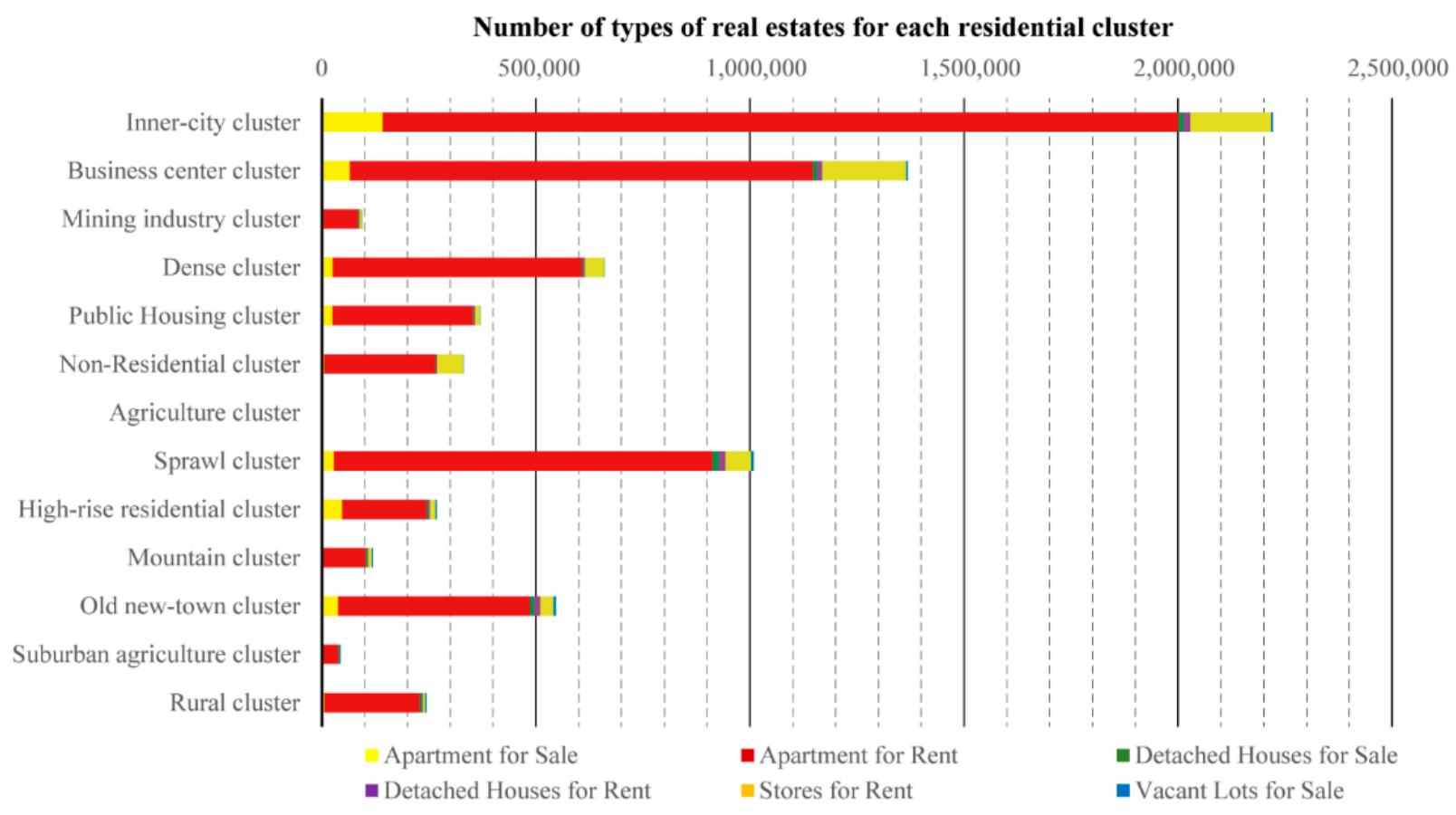

Figure 9. Amount of real estate available in each residential cluster.

Each type of real estate is analyzed in Figure 9 . Figure 9 shows that the most common type was apartments for rent $(\mathrm{N}=6,083,241)$. The cluster with the largest number of these was the inner city cluster $(\mathrm{N}=1,859,217)$. The next largest type was shops for rent $(\mathrm{N}=628,086)$. The cluster with the largest number of these was the business center cluster $(\mathrm{N}=195,922)$.

Next, the real estate prices are plotted for each residential cluster using a boxplot diagram in Figure 10. Figure 10 does not include plot outliers in the boxplot. The real estate includes apartments for sale, apartments for rent, detached houses for sale, detached houses for rent, shops for rent, and vacant lots for sale. The results were analyzed focusing on the median value. Figure 10 shows that the median value did not vary greatly, ranging from $1500 \mathrm{Yen} / \mathrm{m}^{2}$ to $2000 \mathrm{Yen} / \mathrm{m}^{2}$. However, it was found that the real estate prices were higher in the inner city cluster (price $\left.=2022 \mathrm{Yen} / \mathrm{m}^{2}\right)$, business center cluster $\left(\right.$ price $\left.=2124 \mathrm{Yen} / \mathrm{m}^{2}\right)$, dense cluster $\left(\right.$ price $\left.=1923 \mathrm{Yen} / \mathrm{m}^{2}\right)$ and high-rise cluster $\left(\right.$ price $\left.=1771 \mathrm{Yen} / \mathrm{m}^{2}\right)$. On the other hand, it was found that the real estate prices were higher in the public housing cluster (price $=1368 \mathrm{Yen} / \mathrm{m}^{2}$ ), agriculture cluster $\left(\right.$ price $\left.=1438 \mathrm{Yen} / \mathrm{m}^{2}\right)$, suburban agriculture cluster $\left(\right.$ price $\left.=1479 \mathrm{Yen} / \mathrm{m}^{2}\right)$, and rural cluster $\left(\right.$ price $\left.=1323 \mathrm{Yen} / \mathrm{m}^{2}\right)$. 


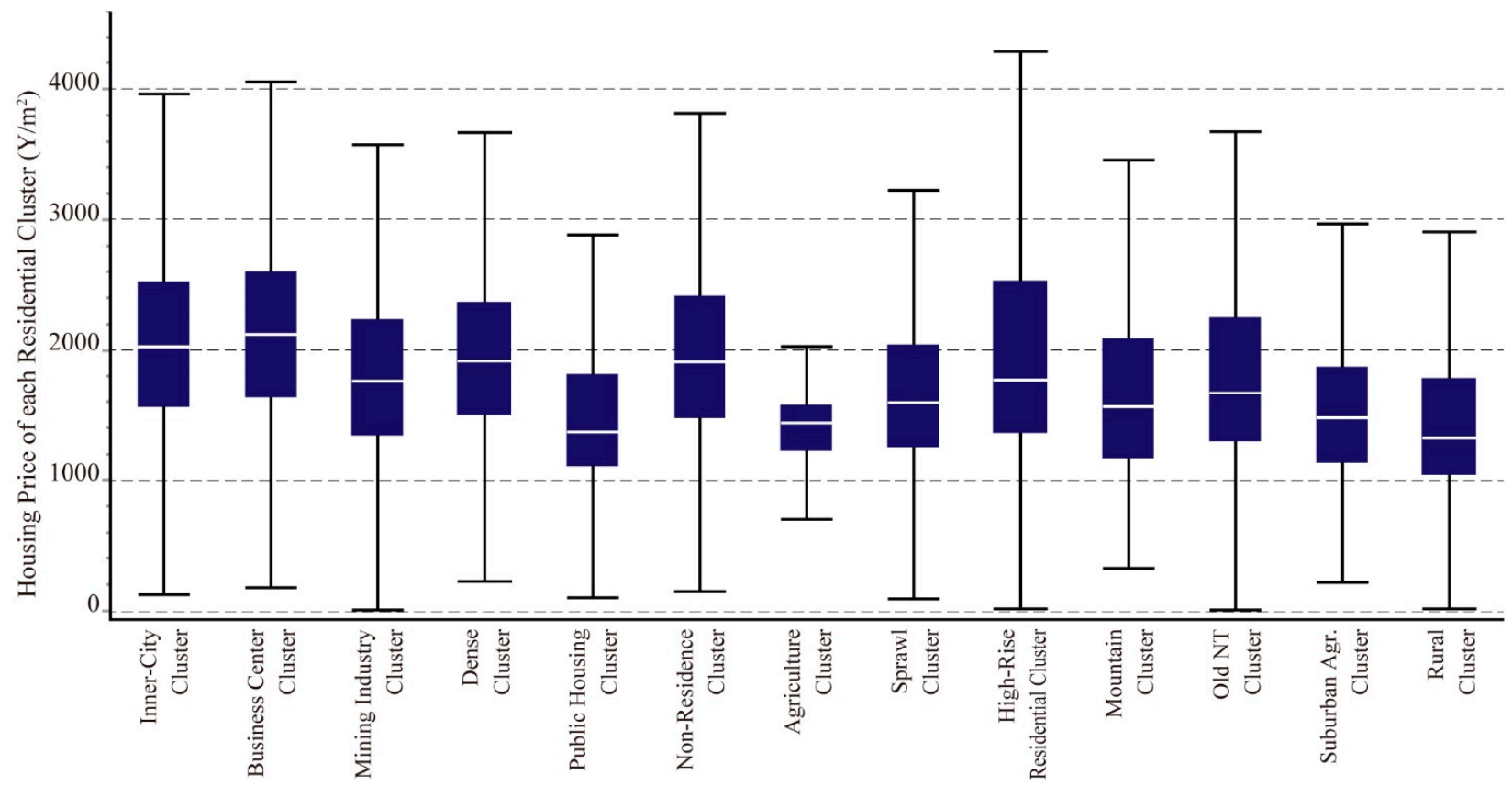

Figure 10. Box plot diagram showing the real estate price of each residential cluster.

Finally, the FPCR 2040 for each residential cluster was analyzed in the boxplot diagram in Figure 11. Figure 11 does not include plot outliers. Focusing on the median value, Figure 11 shows that the future population was expected to decline in all residential clusters. Among the residential clusters, the future population was expected to decline rapidly in the public housing cluster $\left(\mathrm{FPCR}_{2040}=-45.9\right)$ and the mountain cluster $\left(\mathrm{FPCR}_{2040}=-44.7\right)$. However, it was found that the population would decrease by approximately $30 \%$ in the business center cluster $\left(\mathrm{FPCR}_{2040}=-29.7\right)$ and the sprawl cluster $\left(\mathrm{FPCR}_{2040}=-33.2\right)$.

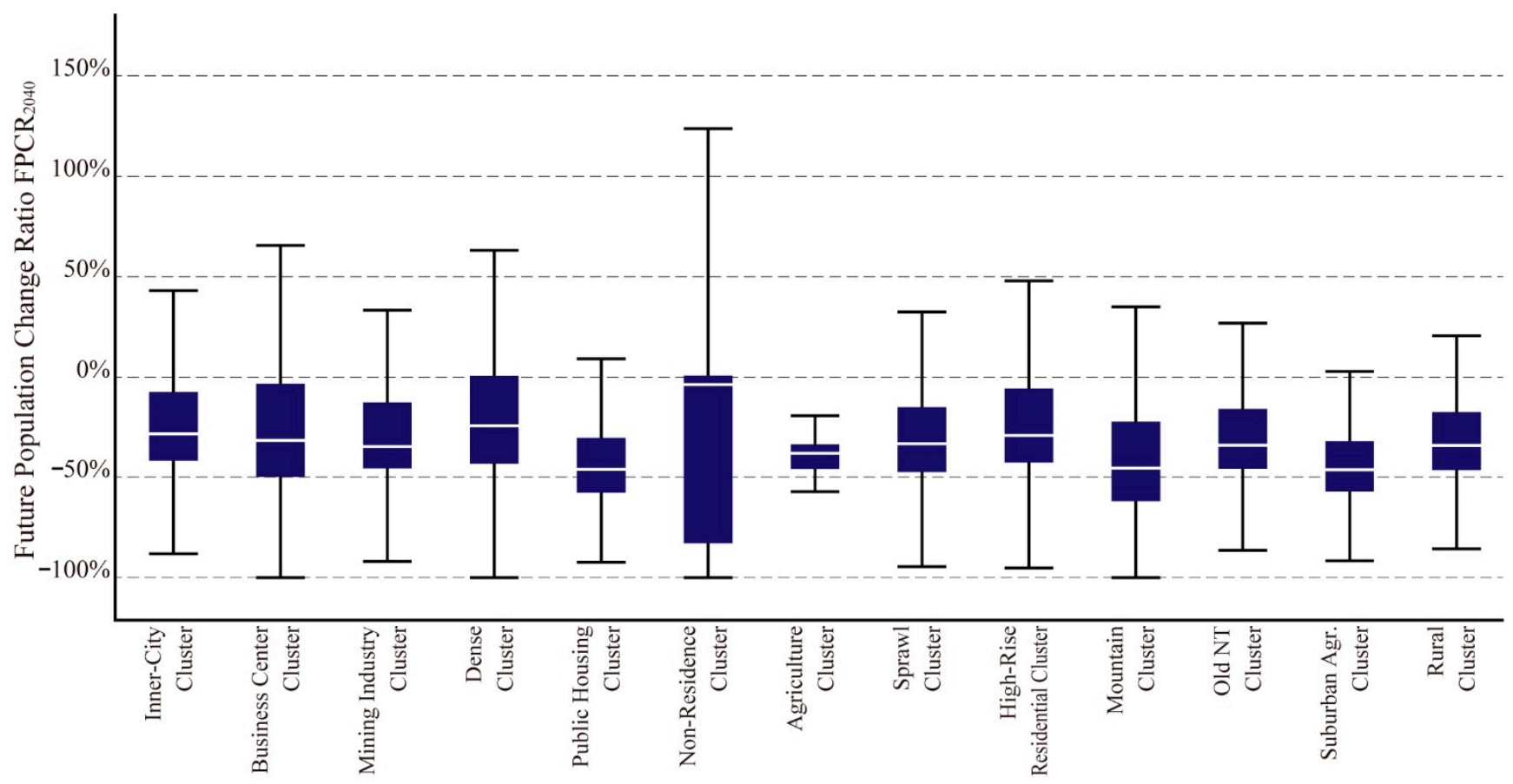

Figure 11. Box plot diagram showing the $\mathrm{FPCR}_{2040}$ of each residential cluster. 


\subsection{Structural Equation Modeling of Residential Clusters}

In this section, we analyze the SEM in which walkability affects real estate prices and real estate prices affect $\mathrm{FPCR}_{2040}$ according to the residential cluster involved. Effective models of residential clusters are clarified in Table 1 based on GFI, AGFI, and RMSEA. Table 1 shows that the effective residential clusters are the business center cluster and the sprawl cluster. The result suggests that, in the business center cluster and the sprawl cluster, walkability affects real estate prices and those real estate prices affect the $\mathrm{FPCR}_{2040}$.

Table 1. Test statistics for the SEM for each cluster.

\begin{tabular}{cccc}
\hline & GFI & AGFI & RMSEA \\
\hline Inner City Cluster & 0.931 & 0.844 & 0.128 \\
Business Center Cluster & 0.966 & 0.924 & 0.094 \\
Mining Industry Cluster & 0.841 & 0.641 & 0.188 \\
Dense Cluster & 0.848 & 0.657 & 0.186 \\
Public Housing Cluster & 0.909 & 0.796 & 0.145 \\
Non-Residential Cluster & 0.905 & 0.787 & 0.155 \\
Agriculture Cluster & 0.603 & 0.107 & 0.337 \\
Sprawl Cluster & 0.961 & 0.912 & 0.092 \\
High-Rise Residential Cluster & 0.788 & 0.522 & 0.239 \\
Mountain Cluster & 0.941 & 0.867 & 0.117 \\
Old NT Cluster & 0.870 & 0.707 & 0.176 \\
Suburban Agriculture Cluster & 0.689 & 0.301 & 0.286 \\
Rural Cluster & 0.764 & 0.470 & 0.233 \\
\hline
\end{tabular}

In the business center cluster, Figure 12 shows that WI has a positive impact on the price of apartments for sale (Path coefficient: P.C. $=1.88$ ) and the price of stores for rent $($ P.C. $=0.44)$. On the other hand, WI has negative impacts on the price of vacant lots for sale (P.C. $=-1.30)$ and the price of detached houses for sale (P.C. $=-0.33)$. Moreover, it was found that the price of real estate had positive impacts on the price of apartments for rent (P.C. $=48.39)$ and the price of detached houses for rent (P.C. $=10.92)$. This result suggests that the price of apartments for sale is a real estate factor in which WI positively impacts $\mathrm{FPCR}_{2040}$. In the business center cluster, this means that, by increasing WI, the price of apartments for sale is expected to increase and the $\mathrm{FPCR}_{2040}$ is also expected to increase.

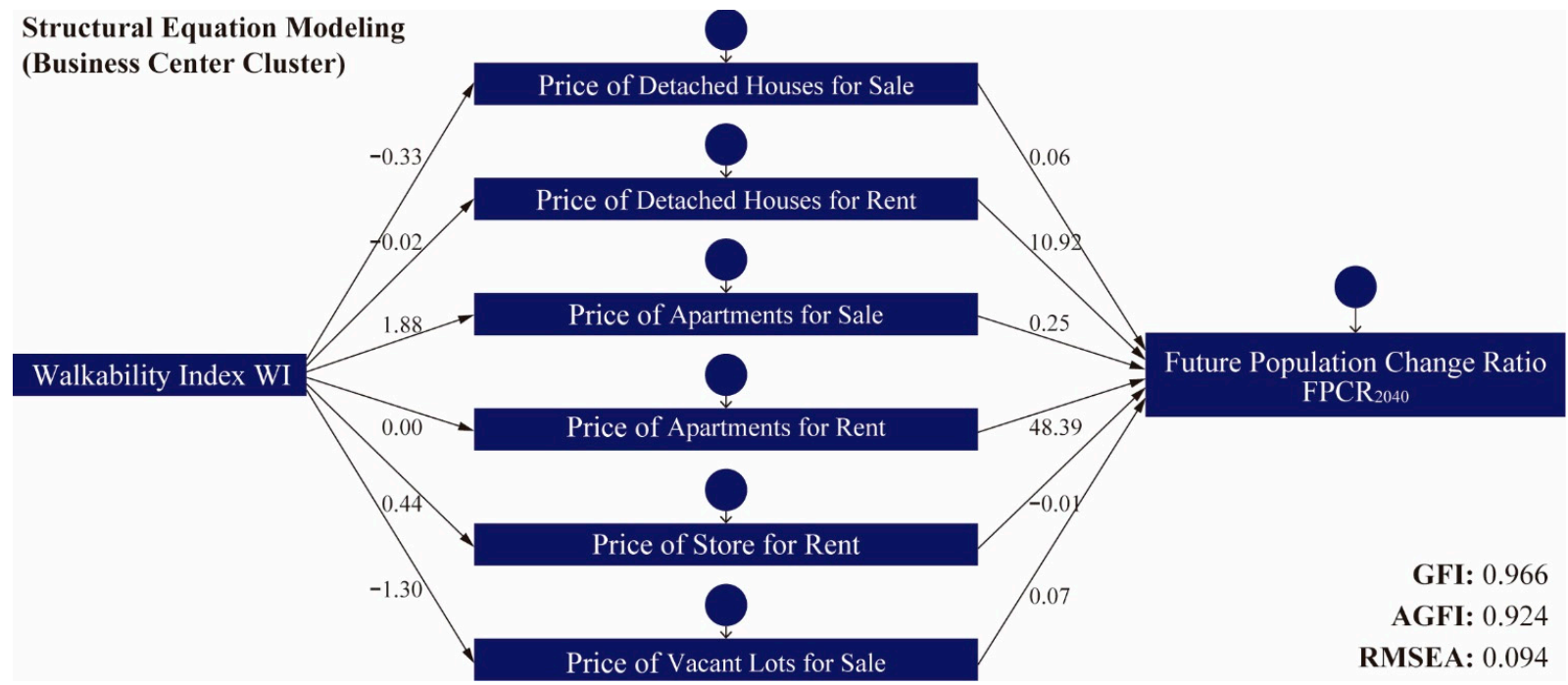

Figure 12. Structural equation modeling of the business center cluster.

In the sprawl cluster, Figure 13 shows that WI has positive impacts on the price of apartments for sale (P.C. $=4.01$ ) and the price of detached houses for sale (P.C. $=1.25)$. 
On the other hand, there is no real estate that has negative impacts on the real estate price. Moreover, many types of real estate prices have a negative impact on the FPCR 2040 . These types are the price of apartments for rent (P.C. $=-14.10)$ and the price of detached houses for rent (P.C. $=-23.78$ ). However, only the price of apartments for sale had a positive impact on $\mathrm{FPCR}_{2040}$. This result suggests that the price of apartments for sale is a real estate factor in which WI has a positive impact on $\mathrm{FPCR}_{2040}$. In the sprawl cluster, this suggestion means that the price of apartments for sale and $\mathrm{FPCR}_{2040}$ are expected to increase by increasing the WI.

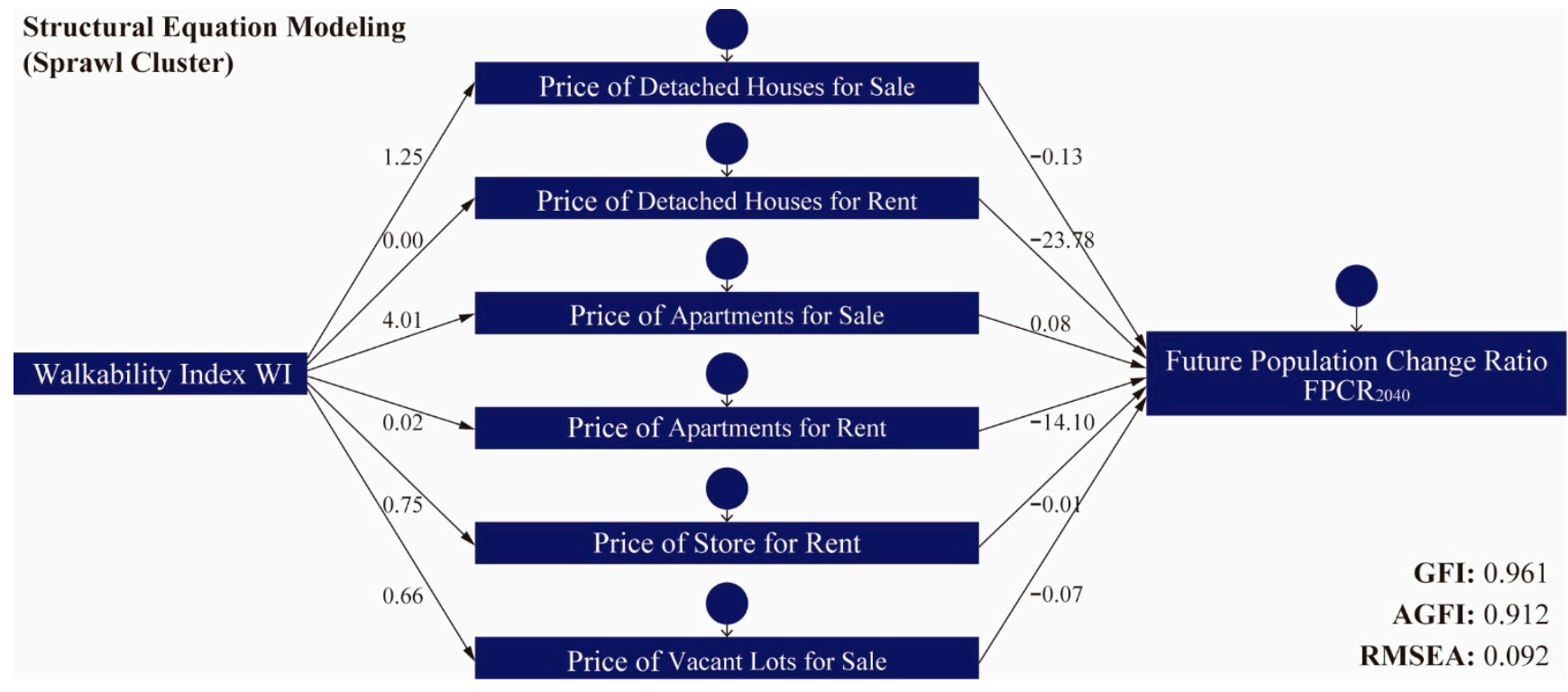

Figure 13. Structural equation modeling of the sprawl cluster.

\section{Discussion}

We conclude that, in the business center cluster and the sprawl cluster, the price of apartments for sale is a real estate factor in which WI positively impacts $F P C R_{2040}$. There are previous studies on walkability and real estate prices and on real estate prices and future population [13-15]. However, there were many theories about the positive and negative influences, and the findings were not always consistent [16-18]. Compared to previous studies, this study clarified the relationship between walkability, real estate prices, and future population according to residential clusters. The method we used was the SEM, for each residential cluster of an NA, of the impact of walkability on the real estate price and the impact of real estate price on $\mathrm{FPCR}_{2040}$, using the walkability index, real estate price, and future population change ratio. This study provided reliable results based on the GFI, AGFI, and RMSEA scores by the SEM. This study was analyzed in the Osaka metropolitan area based on the NA scale.

The results are summarized in Table 2. The SEM was not found to be a valid model for the eleven clusters apart from the business center cluster and the sprawl cluster. The result clarified the effectiveness of the studies of Boyle et al. [16] and Maennig et al. [20] in the eleven clusters. The result suggests that factors other than improving walkability might affect the future population in the eleven clusters. This suggestion meets the need for approaches other than improving walkability in the eleven clusters.

On the other hand, in the business center and sprawl clusters, the results suggest that improving walkability might contribute to sustaining the future population. For improving walkability in the clusters, it was found that apartments for sale are essential. Specifically, WI positively impacts the real estate price of apartments for sale in the business center cluster (P.C. $=1.88$ ) and the sprawl cluster (P.C. $=4.01$ ). This result validates the studies of Kim [18] and Pivo et al. [36]. The results are consistent with a previous study of Brazilian 
cities in the global south [37]. The reason might be that apartments for sale are sometimes developed together with shops and hospitals, which increases the scores of a walkability index (Equation (4)) in ND (Equation (1)) and LUM (Equation (3)). Moreover, the real estate price of apartments for sale has positive impacts on $\mathrm{FPCR}_{2040}$ in the business center cluster (P.C. $=0.25)$ and the sprawl cluster (P.C. $=0.08$ ). This result validates the study of Saita et al. [19]. The reason might be that residents of apartments for sale tend to live there for a long time. This result suggests that, in the business center clusters and the sprawl clusters, the effective use of apartments for sale can contribute to the maintenance of the future population in approaches aiming to improve walkability.

Table 2. Statistical relationships in each residential cluster.

\begin{tabular}{|c|c|c|c|}
\hline & $\begin{array}{l}\text { WI Has Positive Impacts on the } \\
\text { Real Estate Price. }\end{array}$ & $\begin{array}{l}\text { Real Estate Price Has Positive } \\
\text { Impacts on FPCR } \\
2040 .\end{array}$ & $\begin{array}{l}\text { WI Positively Impacts } \\
\text { on FPCR } \\
2040 .\end{array}$ \\
\hline $\begin{array}{l}\text { Business Center } \\
\text { Cluster }\end{array}$ & $\begin{array}{l}\text { Apartments for sale }(\text { P.C. }=1.88) \\
\text { Stores for rent }(\text { P.C. }=0.44)\end{array}$ & $\begin{array}{l}\text { Detached houses for rent (P.C. }=0.06) \\
\text { Detached houses for rent (P.C. }=10.92) \\
\text { Apartments for sale (P.C. }=0.25) \\
\text { Apartments for rent (P.C. }=48.39) \\
\text { Vacant lots for sale (P.C. }=0.07) .\end{array}$ & Apartments for sale \\
\hline Sprawl Cluster & $\begin{array}{c}\text { Detached houses for rent }(\text { P.C. }=1.25) \\
\text { Detached houses for rent (P.C. }=0.00) \\
\text { Apartments for sale (P.C. }=4.01) \\
\text { Apartments for rent (P.C. }=0.02) \\
\text { Stores for rent (P.C. }=0.75) . \\
\text { Vacant lots for sale (P.C. }=0.66) .\end{array}$ & Apartments for sale $($ P.C. $=0.08)$ & Apartments for sale \\
\hline
\end{tabular}

\section{Conclusions}

In the future, walkable neighborhoods need to be designed according to the characteristics of each residential cluster. The result of this study is worth it for urban planners to suggest that a combination of effective housing policies and the design of walkable neighborhoods is expected to achieve promising results. Japanese housing policy is positioned in the dualist rental model suggested by Kemeny [38]. Therefore, the houses are mainly traded on the private market. That means that this research result would be highly effective in Japan. With its aging society, Japan also needs to redesign walkable neighborhoods strategically in order to prevent rapid population decline. In addition, while the concept of a 15-min city has been discussed [39], this study is valuable for raising new possibilities for urban projects related to walkable design.

In the business center cluster in the Osaka metropolitan area, Midosuji Street in central Osaka has been designed as a walkable street [40]. The city center of Kyoto has also been designated a walkable area as an urban strategy [41]. In addition to these walkable designs, it is expected that the future population will be sustained by strategically locating apartments for sale in the business center cluster. This means that there is a need for a housing policy for apartments for sale in the business center cluster. If real estate types other than apartments for sale are located there, there will be a risk of gentrification, which will cause population decline, as in the central area of Kyoto City [22]. Therefore, policies to guide urban development, including apartments for sale, would be effective in the business center cluster.

For the sprawl cluster in the Osaka metropolitan area, no successful designs to improve walkability have been reported yet. However, diversifying land use could be effective. Kato [10] reported that the creation of medical facilities and welfare facilities could help maintain the future population in the sprawl cluster. By strategically locating such facilities on land made vacant by population decline, it may be possible to maintain the population. In the sprawl cluster, housing stock has been rebuilt because many areas were developed after the 1960s. Therefore, in addition to land use diversification, when rebuilding old building stock using the location optimization plan policy, it would be effective to maintain 
the future population by developing a housing policy that proactively locates apartments for sale in residential-inducing areas in the sprawl cluster.

A future task of this research group is to develop policies to realize the proposed method in the business center cluster and sprawl cluster. Methods that succeed in Japan, where population decline is projected, are expected to become a model for urban policies in shrinking cities worldwide.

There are two main limitations of this study. The first limitation is that we could not clarify factors other than walkability in eleven clusters apart from the business center cluster and the sprawl cluster. This factor needs to be investigated further in the future. The second limitation is the analysis of the NA scale. For example, we cannot identify changes in individual real estate prices by increasing walkability. In order to clarify the changes in particular real estate prices, it is necessary to evaluate walkability at the street or building scale. This analysis needs to be investigated further in the future.

Author Contributions: Conceptualization, H.K.; methodology, H.K.; software, H.K.; validation, H.K. and A.T.; formal analysis, H.K.; investigation, H.K.; resources, H.K.; data curation, H.K.; writingoriginal draft preparation, H.K.; writing—review and editing, H.K. and A.T.; visualization, H.K.; supervision, H.K.; project administration, H.K.; funding acquisition, H.K. All authors have read and agreed to the published version of the manuscript.

Funding: This research was funded by the JSPS KAKENHI (21K14318) and the Association of Real Estate Agents of Japan.

Institutional Review Board Statement: Not applicable.

Informed Consent Statement: Not applicable.

Data Availability Statement: The data presented in this study are available on request from the corresponding author, H.K.

Acknowledgments: In this paper, we used the "At Home Dataset" provided by At Home Co., Ltd., via IDR Dataset Service of National Institute of Informatics. This study was undertaken using data provided by the Conservation GIS Consortium Japan.

Conflicts of Interest: The author declares no conflict of interest.

\section{Appendix A}

This section draws upon the author's previous study $[5,8,10]$. The types of clusters present using urban ecological analysis were analyzed in the Osaka metropolitan area, the same region and data as that studied in this paper $[5,8,10]$. Urban ecological analysis aims to identify geospatial patterns through an inductive method using a wide range of statistical data on the NA scale. This analysis consisted of five steps. First, the 2015 Japanese census was analyzed using the standardization of the 53 identified indicators. The 53 indicators were census data such as "population under 15 years old", "households who live in detached houses", and "population who work in their own city". Next, the standardized composition ratio $R_{x}^{k}$ was calculated by standardizing each indicator's data using Equation (A1):

$$
R_{x}^{k}=\frac{X_{x i}^{k}-X_{x \min }}{X_{x \max }-X_{x \min }}
$$

where $X_{x i}^{k}$ is the number of $\mathrm{NA}_{i}$ for indicator $\mathrm{x}$ in the $\mathrm{NA}_{k}, \mathrm{X}_{x \min }$ is the minimum value of $\mathrm{NA}_{i}$ for indicator $\mathrm{x}$, and $X_{x \max }$ is the maximum value of $\mathrm{NA}_{i}$ for indicator $x$.

Third, using $R_{x}^{k}$, the principal component was analyzed. The social survey data were deemed reliable because the Cronbach's $\alpha$ coefficient of the principal component analysis was 0.985 . Fourth, using the Kaiser criterion, seven principal components were extracted. The obtained data were reliable because the total variable amount of these seven principal components was $78.8 \%$. Finally, using their seven principal component scores, residential clusters were categorized using hierarchical cluster analysis. 
In addition to the urban ecological analysis, this study analyzed the urbanized area ratio and the average distance from the center. The urbanized area ratio was analyzed using the National Land Information Download Service provided by the Ministry of Land, Infrastructure, Transport, and Tourism of Japan [42]. The urbanized area ratio was the ratio of the NA that were designated as urbanized areas by their local governments. The average distance from the center of the metropolitan area-Umeda in Osaka city, Karasuma in Kyoto city, and Sannomiya Station in Kobe City-was then calculated. Then, by analyzing the $\mathrm{R}_{\mathrm{ki}}$, urbanized area ratio, and average distance from the center of each indicator for each residential cluster, each cluster's name was determined, as shown in Table A1. Finally, the cluster classification was verified by analyzing the average land use area $\left(\mathrm{m}^{2}\right)$ using the data of the Numerical Map 5000 for Japan [33] in Table A1.

Table A1. The $R_{k i}$ of each indicator for each residential cluster (Table A1 features the same data as Table A.1 and Table A.2 from Kato [8]).

\begin{tabular}{|c|c|c|c|c|c|c|c|c|c|c|c|c|c|c|}
\hline & Heading & 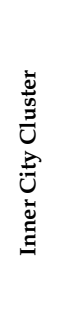 & 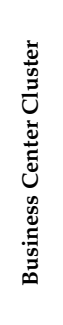 & 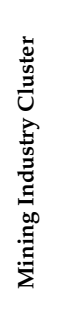 & 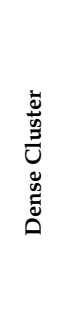 & 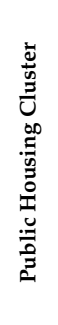 & 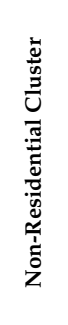 & 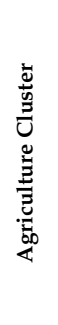 & 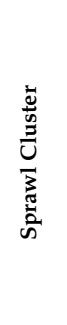 & 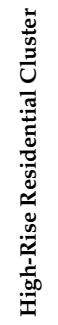 & 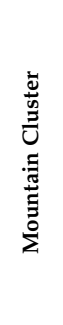 & 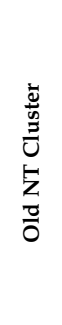 & 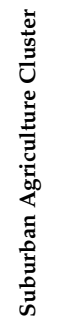 & 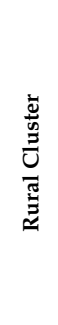 \\
\hline & $\begin{array}{c}\text { Number of NA in the } \\
\text { cluster }(\mathrm{N})\end{array}$ & 1937 & 5472 & 728 & 672 & 889 & 7403 & 297 & 4998 & 628 & 7251 & 2546 & 2914 & 1033 \\
\hline \multirow{2}{*}{$\begin{array}{c}\text { Location } \\
\text { data by } \\
\text { GIS } \\
\text { analysis }\end{array}$} & $\begin{array}{l}\text { Urbanized area ratio } \\
(\%)\end{array}$ & 84.5 & 86.2 & 45.1 & 77.1 & 72.4 & 55.2 & 23.6 & 66.2 & 61.8 & 40.7 & 59.1 & 21.3 & 24.9 \\
\hline & $\begin{array}{l}\text { Average distance } \\
\text { from the center }(\mathrm{km})\end{array}$ & 19.3 & 34.5 & 59.9 & 31.2 & 26.7 & 43.9 & 71.6 & 38.2 & 25.9 & 56.1 & 26.7 & 63.1 & 52.1 \\
\hline \multirow{17}{*}{$\begin{array}{c}\text { Census } \\
\text { data of } \\
2015 \\
\text { Japanese } \\
\text { census }\end{array}$} & $\begin{array}{l}\text { Population under } 15 \\
\text { years old (\%) }\end{array}$ & 0.06 & 0.01 & 0.03 & 0.06 & 0.05 & 0.00 & 0.04 & 0.02 & 0.09 & 0.01 & 0.03 & 0.01 & 0.10 \\
\hline & $\begin{array}{l}\text { Population between } \\
16 \text { and } 64 \text { years old } \\
(\%)\end{array}$ & 0.09 & 0.02 & 0.04 & 0.09 & 0.08 & 0.00 & 0.06 & 0.03 & 0.12 & 0.01 & 0.05 & 0.02 & 0.14 \\
\hline & $\begin{array}{l}\text { Population over } 65 \\
\text { years old }(\%)\end{array}$ & 0.10 & 0.02 & 0.04 & 0.07 & 0.12 & 0.00 & 0.09 & 0.04 & 0.11 & 0.01 & 0.05 & 0.03 & 0.15 \\
\hline & $\begin{array}{l}\text { Population of } \\
\text { foreigners (\%) }\end{array}$ & 0.09 & 0.02 & 0.02 & 0.04 & 0.07 & 0.00 & 0.01 & 0.02 & 0.03 & 0.00 & 0.01 & 0.00 & 0.05 \\
\hline & $\begin{array}{l}\text { Population who live } \\
\text { in their own houses } \\
(\%)\end{array}$ & 0.09 & 0.02 & 0.04 & 0.07 & 0.05 & 0.00 & 0.07 & 0.03 & 0.13 & 0.01 & 0.05 & 0.02 & 0.15 \\
\hline & $\begin{array}{l}\text { Population who live } \\
\text { in public housing (\%) }\end{array}$ & 0.01 & 0.00 & 0.00 & 0.01 & 0.12 & 0.00 & 0.01 & 0.00 & 0.01 & 0.00 & 0.00 & 0.00 & 0.01 \\
\hline & $\begin{array}{l}\text { Population who live } \\
\text { in private rented } \\
\text { houses }(\%)\end{array}$ & 0.10 & 0.02 & 0.02 & 0.10 & 0.02 & 0.00 & 0.02 & 0.03 & 0.05 & 0.00 & 0.02 & 0.00 & 0.07 \\
\hline & $\begin{array}{l}\text { Population who live } \\
\text { in houses for } \\
\text { employees (\%) }\end{array}$ & 0.02 & 0.00 & 0.01 & 0.08 & 0.01 & 0.00 & 0.01 & 0.01 & 0.02 & 0.00 & 0.01 & 0.00 & 0.02 \\
\hline & $\begin{array}{l}\text { Population who live } \\
\text { in shared houses (\%) }\end{array}$ & 0.08 & 0.02 & 0.02 & 0.05 & 0.03 & 0.00 & 0.04 & 0.03 & 0.06 & 0.01 & 0.03 & 0.01 & 0.09 \\
\hline & $\begin{array}{l}\text { Households who live } \\
\text { outside of houses (\%) }\end{array}$ & 0.00 & 0.00 & 0.00 & 0.03 & 0.00 & 0.00 & 0.00 & 0.00 & 0.00 & 0.00 & 0.00 & 0.00 & 0.01 \\
\hline & $\begin{array}{l}\text { Households who live } \\
\text { in detached houses } \\
\qquad(\%)\end{array}$ & 0.07 & 0.02 & 0.05 & 0.05 & 0.03 & 0.00 & 0.10 & 0.04 & 0.09 & 0.02 & 0.06 & 0.03 & 0.19 \\
\hline & $\begin{array}{c}\text { Households who live } \\
\text { in traditional nagaya } \\
\text { houses }(\%)\end{array}$ & 0.08 & 0.01 & 0.02 & 0.03 & 0.02 & 0.00 & 0.02 & 0.03 & 0.02 & 0.00 & 0.01 & 0.00 & 0.07 \\
\hline & $\begin{array}{l}\text { Households who live } \\
\text { in apartments }(\%)\end{array}$ & 0.08 & 0.02 & 0.02 & 0.08 & 0.10 & 0.00 & 0.01 & 0.02 & 0.08 & 0.00 & 0.02 & 0.00 & 0.04 \\
\hline & $\begin{array}{l}\text { Households who live } \\
\text { in 1- or 2-story } \\
\text { buildings (\%) }\end{array}$ & 0.05 & 0.02 & 0.04 & 0.07 & 0.02 & 0.00 & 0.04 & 0.05 & 0.05 & 0.00 & 0.03 & 0.01 & 0.16 \\
\hline & $\begin{array}{l}\text { Households who live } \\
\text { in 3- to } 5 \text {-story } \\
\text { buildings (\%) }\end{array}$ & 0.05 & 0.01 & 0.01 & 0.07 & 0.11 & 0.00 & 0.01 & 0.02 & 0.05 & 0.00 & 0.01 & 0.00 & 0.03 \\
\hline & $\begin{array}{l}\text { Households who live } \\
\text { in } 6 \text { - to } 10 \text {-story } \\
\text { buildings }(\%)\end{array}$ & 0.06 & 0.01 & 0.01 & 0.06 & 0.04 & 0.00 & 0.00 & 0.01 & 0.05 & 0.00 & 0.01 & 0.00 & 0.02 \\
\hline & $\begin{array}{l}\text { Households who live } \\
\text { in } 11 \text { (or more)-story } \\
\text { buildings }(\%)\end{array}$ & 0.03 & 0.00 & 0.00 & 0.02 & 0.04 & 0.00 & 0.00 & 0.00 & 0.04 & 0.00 & 0.01 & 0.00 & 0.00 \\
\hline
\end{tabular}


Table A1. Cont.

\begin{tabular}{|c|c|c|c|c|c|c|c|c|c|c|c|c|c|}
\hline Heading & 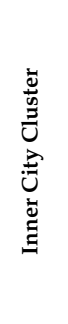 & 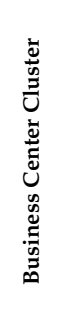 & 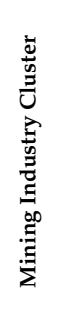 & 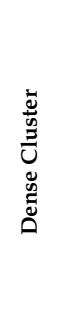 & 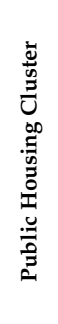 & 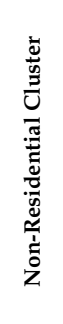 & 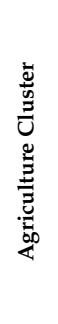 & 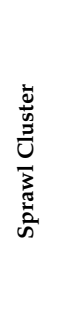 & 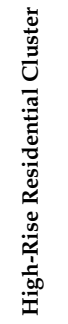 & 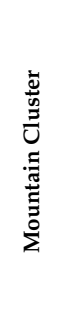 & 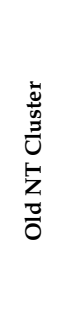 & 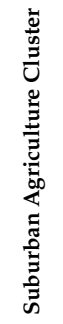 & 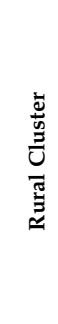 \\
\hline $\begin{array}{l}\text { Population who work } \\
\text { in agriculture and } \\
\text { forestry }(\%)\end{array}$ & 0.00 & 0.00 & 0.01 & 0.00 & 0.00 & 0.00 & 0.13 & 0.00 & 0.01 & 0.01 & 0.00 & 0.03 & 0.03 \\
\hline $\begin{array}{l}\text { Population who work } \\
\text { in a fishery }(\%)\end{array}$ & 0.00 & 0.00 & 0.01 & 0.00 & 0.00 & 0.00 & 0.04 & 0.00 & 0.00 & 0.00 & 0.00 & 0.00 & 0.00 \\
\hline $\begin{array}{l}\text { Population who work } \\
\text { in the mining } \\
\text { industry }(\%)\end{array}$ & 0.00 & 0.00 & 0.09 & 0.00 & 0.00 & 0.00 & 0.05 & 0.00 & 0.00 & 0.00 & 0.00 & 0.00 & 0.01 \\
\hline $\begin{array}{l}\text { Population who work } \\
\text { in the construction } \\
\text { industry }(\%)\end{array}$ & 0.08 & 0.01 & 0.04 & 0.06 & 0.07 & 0.00 & 0.07 & 0.04 & 0.09 & 0.01 & 0.04 & 0.02 & 0.15 \\
\hline $\begin{array}{l}\text { Population who work } \\
\text { in the manufacturing } \\
\text { industry }(\%)\end{array}$ & 0.05 & 0.01 & 0.03 & 0.07 & 0.05 & 0.00 & 0.05 & 0.03 & 0.08 & 0.01 & 0.03 & 0.02 & 0.12 \\
\hline $\begin{array}{l}\text { Population who work } \\
\text { in the electricity, gas, } \\
\text { and water supply } \\
\text { industries }(\%)\end{array}$ & 0.01 & 0.00 & 0.01 & 0.02 & 0.01 & 0.00 & 0.01 & 0.01 & 0.03 & 0.00 & 0.01 & 0.00 & 0.03 \\
\hline $\begin{array}{l}\text { Population who work } \\
\text { in the information } \\
\text { industry }(\%)\end{array}$ & 0.08 & 0.01 & 0.02 & 0.08 & 0.04 & 0.00 & 0.01 & 0.02 & 0.12 & 0.00 & 0.04 & 0.00 & 0.06 \\
\hline $\begin{array}{l}\text { Population who work } \\
\text { in the transport } \\
\text { industry }(\%)\end{array}$ & 0.08 & 0.02 & 0.03 & 0.07 & 0.10 & 0.00 & 0.05 & 0.04 & 0.09 & 0.01 & 0.04 & 0.02 & 0.14 \\
\hline $\begin{array}{l}\text { Population who work } \\
\text { in the retail industry } \\
(\%)\end{array}$ & 0.09 & 0.02 & 0.03 & 0.08 & 0.07 & 0.00 & 0.06 & 0.03 & 0.12 & 0.01 & 0.04 & 0.02 & 0.13 \\
\hline $\begin{array}{l}\text { Population who work } \\
\text { in the financial } \\
\text { industry }(\%)\end{array}$ & 0.06 & 0.01 & 0.02 & 0.08 & 0.04 & 0.00 & 0.03 & 0.02 & 0.12 & 0.00 & 0.04 & 0.01 & 0.08 \\
\hline $\begin{array}{l}\text { Population who work } \\
\text { in the real estate } \\
\text { business }(\%)\end{array}$ & 0.09 & 0.02 & 0.03 & 0.08 & 0.06 & 0.00 & 0.02 & 0.03 & 0.12 & 0.01 & 0.04 & 0.01 & 0.08 \\
\hline $\begin{array}{l}\text { Population who work } \\
\text { as researchers or } \\
\text { professionals (\%) }\end{array}$ & 0.06 & 0.01 & 0.02 & 0.07 & 0.04 & 0.00 & 0.03 & 0.02 & 0.11 & 0.01 & 0.04 & 0.01 & 0.07 \\
\hline $\begin{array}{l}\text { Population who work } \\
\text { in the service } \\
\text { industry (\%) }\end{array}$ & 0.09 & 0.02 & 0.03 & 0.07 & 0.07 & 0.00 & 0.06 & 0.03 & 0.09 & 0.01 & 0.04 & 0.01 & 0.12 \\
\hline $\begin{array}{l}\text { Population who work } \\
\text { in the entertainment } \\
\text { industry }(\%)\end{array}$ & 0.06 & 0.01 & 0.02 & 0.05 & 0.05 & 0.00 & 0.04 & 0.02 & 0.07 & 0.01 & 0.03 & 0.01 & 0.09 \\
\hline $\begin{array}{l}\text { Population who work } \\
\text { in education }(\%)\end{array}$ & 0.06 & 0.02 & 0.03 & 0.08 & 0.04 & 0.00 & 0.05 & 0.02 & 0.13 & 0.01 & 0.05 & 0.02 & 0.10 \\
\hline $\begin{array}{c}\text { Population who work } \\
\text { in the } \\
\text { medical/welfare } \\
\text { industry }(\%)\end{array}$ & 0.07 & 0.02 & 0.03 & 0.07 & 0.07 & 0.00 & 0.06 & 0.03 & 0.11 & 0.01 & 0.04 & 0.02 & 0.13 \\
\hline $\begin{array}{l}\text { Population who work } \\
\text { in a joint service } \\
\text { industry }(\%)\end{array}$ & 0.05 & 0.01 & 0.05 & 0.06 & 0.05 & 0.00 & 0.18 & 0.03 & 0.09 & 0.02 & 0.04 & 0.05 & 0.18 \\
\hline $\begin{array}{l}\text { Population who work } \\
\text { in another service } \\
\text { industry }(\%)\end{array}$ & 0.09 & 0.02 & 0.04 & 0.08 & 0.10 & 0.00 & 0.06 & 0.04 & 0.11 & 0.01 & 0.04 & 0.02 & 0.14 \\
\hline $\begin{array}{l}\text { Population who work } \\
\text { as civil servants (\%) }\end{array}$ & 0.02 & 0.00 & 0.01 & 0.05 & 0.01 & 0.00 & 0.02 & 0.01 & 0.04 & 0.00 & 0.01 & 0.01 & 0.04 \\
\hline $\begin{array}{c}\text { Population who work } \\
\text { at home }(\%)\end{array}$ & 0.08 & 0.02 & 0.04 & 0.06 & 0.04 & 0.00 & 0.18 & 0.03 & 0.07 & 0.01 & 0.03 & 0.05 & 0.13 \\
\hline $\begin{array}{l}\text { Population who work } \\
\text { in their own city }(\%)\end{array}$ & 0.06 & 0.01 & 0.04 & 0.07 & 0.06 & 0.00 & 0.07 & 0.03 & 0.07 & 0.01 & 0.03 & 0.02 & 0.14 \\
\hline $\begin{array}{l}\text { Population who work } \\
\text { in other cities (\%) }\end{array}$ & 0.07 & 0.01 & 0.03 & 0.07 & 0.06 & 0.00 & 0.04 & 0.02 & 0.11 & 0.01 & 0.04 & 0.01 & 0.10 \\
\hline $\begin{array}{l}\text { Population who work } \\
\text { in other wards of } \\
\text { their own cities (\%) }\end{array}$ & 0.07 & 0.01 & 0.01 & 0.01 & 0.03 & 0.00 & 0.00 & 0.00 & 0.01 & 0.00 & 0.00 & 0.00 & 0.00 \\
\hline $\begin{array}{l}\text { Population who work } \\
\text { in other cities of their } \\
\text { own prefectures }(\%)\end{array}$ & 0.03 & 0.00 & 0.02 & 0.07 & 0.05 & 0.00 & 0.05 & 0.03 & 0.09 & 0.01 & 0.04 & 0.01 & 0.12 \\
\hline $\begin{array}{c}\text { Population who work } \\
\text { in other prefectures } \\
(\%)\end{array}$ & 0.03 & 0.01 & 0.02 & 0.07 & 0.03 & 0.00 & 0.01 & 0.01 & 0.15 & 0.00 & 0.05 & 0.01 & 0.05 \\
\hline
\end{tabular}


Table A1. Cont.

\begin{tabular}{|c|c|c|c|c|c|c|c|c|c|c|c|c|c|c|}
\hline & Heading & 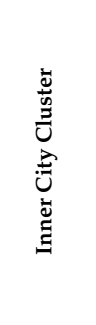 & 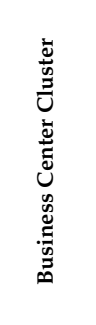 & 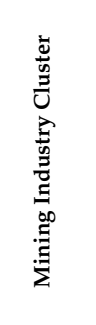 & 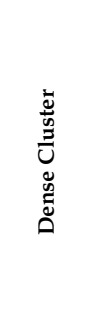 & 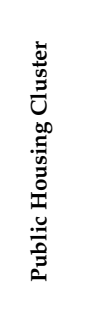 & 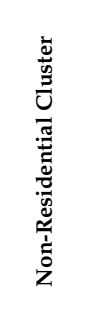 & 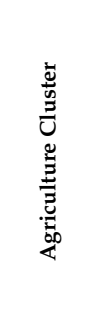 & 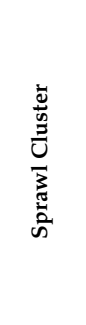 & 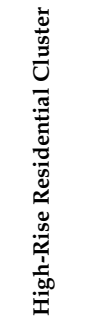 & 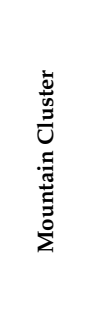 & 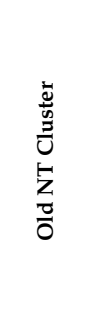 & 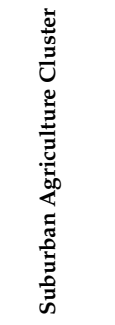 & 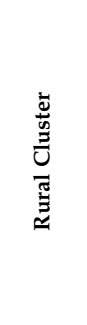 \\
\hline & $\begin{array}{l}\text { Population who go to } \\
\text { school in their own } \\
\text { city }(\%)\end{array}$ & 0.04 & 0.01 & 0.02 & 0.06 & 0.04 & 0.00 & 0.04 & 0.02 & 0.07 & 0.01 & 0.03 & 0.01 & 0.09 \\
\hline & $\begin{array}{l}\text { Population who go to } \\
\text { school in other cities } \\
(\%)\end{array}$ & 0.07 & 0.01 & 0.03 & 0.06 & 0.06 & 0.00 & 0.04 & 0.03 & 0.14 & 0.01 & 0.05 & 0.01 & 0.11 \\
\hline & $\begin{array}{l}\text { Population who go to } \\
\text { school in other wards } \\
\text { of their own cities (\%) }\end{array}$ & 0.07 & 0.02 & 0.01 & 0.01 & 0.03 & 0.00 & 0.00 & 0.00 & 0.01 & 0.00 & 0.00 & 0.00 & 0.00 \\
\hline & $\begin{array}{c}\text { Population who go to } \\
\text { school in other cities } \\
\text { of their own } \\
\text { prefectures }(\%)\end{array}$ & 0.04 & 0.01 & 0.03 & 0.06 & 0.06 & 0.00 & 0.06 & 0.03 & 0.13 & 0.01 & 0.05 & 0.02 & 0.13 \\
\hline & $\begin{array}{l}\text { Population who go to } \\
\text { school in other } \\
\text { prefectures (\%) }\end{array}$ & 0.04 & 0.01 & 0.02 & 0.06 & 0.03 & 0.00 & 0.03 & 0.02 & 0.16 & 0.01 & 0.05 & 0.01 & 0.08 \\
\hline & $\begin{array}{l}\text { Population who have } \\
\text { lived in the area since } \\
\text { birth }(\%)\end{array}$ & 0.07 & 0.02 & 0.05 & 0.06 & 0.05 & 0.00 & 0.13 & 0.04 & 0.10 & 0.02 & 0.04 & 0.05 & 0.17 \\
\hline & $\begin{array}{c}\text { Population who have } \\
\text { lived in the area for } 1 \\
\text { year }(\%)\end{array}$ & 0.06 & 0.02 & 0.02 & 0.10 & 0.05 & 0.00 & 0.03 & 0.03 & 0.07 & 0.00 & 0.03 & 0.01 & 0.08 \\
\hline & $\begin{array}{l}\text { Population who have } \\
\text { lived in the area for } \\
\text { the past } 5 \text { years }(\%)\end{array}$ & 0.06 & 0.01 & 0.02 & 0.08 & 0.06 & 0.00 & 0.03 & 0.02 & 0.08 & 0.00 & 0.03 & 0.01 & 0.09 \\
\hline & $\begin{array}{l}\text { Population who have } \\
\text { lived in the area for } \\
\text { the past } 10 \text { years }(\%)\end{array}$ & 0.07 & 0.01 & 0.03 & 0.07 & 0.07 & 0.00 & 0.04 & 0.03 & 0.12 & 0.01 & 0.04 & 0.01 & 0.11 \\
\hline & $\begin{array}{l}\text { Population who have } \\
\text { lived in the area for } \\
\text { the past } 20 \text { years }(\%)\end{array}$ & 0.08 & 0.02 & 0.03 & 0.07 & 0.08 & 0.00 & 0.05 & 0.03 & 0.15 & 0.01 & 0.05 & 0.01 & 0.13 \\
\hline & $\begin{array}{l}\text { Population who have } \\
\text { lived in the area for } \\
\text { over } 20 \text { years }(\%)\end{array}$ & 0.07 & 0.02 & 0.04 & 0.05 & 0.08 & 0.00 & 0.08 & 0.03 & 0.09 & 0.01 & 0.05 & 0.02 & 0.15 \\
\hline \multirow{12}{*}{$\begin{array}{l}\text { Land use } \\
\text { data of } \\
\text { Numeri- } \\
\text { cal Map } \\
5000 \text { in } \\
\text { Japan }\end{array}$} & $\begin{array}{l}\text { Public facilities land } \\
\left(\mathrm{m}^{2}\right)\end{array}$ & 39,637 & 18,936 & 24,393 & 65,205 & 32,639 & 40,830 & 32,143 & 33,208 & 41,080 & 17,951 & 23,897 & 19,784 & 34,391 \\
\hline & $\begin{array}{l}\text { Low-rise residential } \\
\text { land }\left(\mathrm{m}^{2}\right)\end{array}$ & 32,789 & 13,485 & 35,363 & 28,848 & 19,301 & 3504 & 111,001 & 26,419 & 48,553 & 17,373 & 39,973 & 41,492 & 72,239 \\
\hline & $\begin{array}{l}\text { High-rise residential } \\
\text { land }\left(\mathrm{m}^{2}\right)\end{array}$ & 9053 & 1632 & 4380 & 14,971 & 39,734 & 583 & 525 & 3654 & 21,313 & 807 & 4928 & 701 & 6887 \\
\hline & Park green land $\left(\mathrm{m}^{2}\right)$ & 11,649 & 5947 & 9426 & 10,631 & 14,580 & 13,580 & 41,421 & 7421 & 14,513 & 7716 & 7405 & 15,447 & 17,434 \\
\hline & $\begin{array}{c}\text { Commercial facilities } \\
\text { land }\left(\mathrm{m}^{2}\right)\end{array}$ & 17,635 & 7810 & 10,736 & 20,405 & 10,950 & 11,914 & 31,938 & 11,282 & 13,067 & 6388 & 7436 & 14,571 & 24,132 \\
\hline & $\begin{array}{l}\text { Dense residential } \\
\text { land }\left(\mathrm{m}^{2}\right)\end{array}$ & 5531 & 1619 & 5025 & 3073 & 2458 & 265 & 4379 & 4163 & 2633 & 1325 & 3540 & 933 & 11,780 \\
\hline & $\begin{array}{l}\text { Mountain forest } \\
\text { land }\left(\mathrm{m}^{2}\right)\end{array}$ & 109,634 & 205,136 & 419,545 & 196,341 & 56,359 & 652,836 & $2,742,099$ & 66,609 & 216,845 & 676,535 & 272,460 & $2,120,660$ & 628,045 \\
\hline & Industrial land $\left(\mathrm{m}^{2}\right)$ & 6192 & 3303 & 7430 & 8553 & 5245 & 18,729 & 34,147 & 7846 & 5047 & 5513 & 3327 & 12,189 & 15,315 \\
\hline & Rice field $\left(\mathrm{m}^{2}\right)$ & 4655 & 3102 & 11,091 & 5342 & 3631 & 10,420 & 248,038 & 5034 & 3573 & 14,977 & 3650 & 107,506 & 46,223 \\
\hline & Farm land $\left(\mathrm{m}^{2}\right)$ & 3541 & 1619 & 7553 & 2688 & 3490 & 3963 & 175,850 & 4020 & 3076 & 9034 & 2929 & 73,126 & 35,252 \\
\hline & Vacant land $\left(\mathrm{m}^{2}\right)$ & 7493 & 3565 & 9145 & 11,319 & 7761 & 7413 & 60,975 & 6932 & 12,634 & 6345 & 9059 & 23,757 & 23,063 \\
\hline & developing land $\left(\mathrm{m}^{2}\right)$ & 275 & 745 & 3244 & 283 & 64 & 5920 & 3203 & 1890 & 355 & 1699 & 2028 & 5318 & 2704 \\
\hline
\end{tabular}

\section{References}

1. Japan National Institute of Population and Social Security Research. Population and Social Security in Japan 2019. In IPSS Research Report; Japan National Institute of Population and Social Security Research: Tokyo, Japan, 2019; p. 85.

2. Kato, H.; Kanki, K. Development of walkability indicator for visualising smart shrinking-A case study of sprawl areas in North Osaka Metropolitan Region. Int. Rev. Spat. Plan. Sustain. Dev. 2020, 8, 39-58. [CrossRef]

3. Cerin, E.; Saelens, B.E.; Sallis, J.F.; Frank, L.D. Neighborhood environment walkability scale: Validity and development of a short form. Med. Sci. Sports Exerc. 2006, 38, 1682-1691. [CrossRef]

4. Inoue, S.; Murase, N.; Shimomitsu, T.; Ohya, Y.; Odagiri, Y.; Takamiya, T.; Ishii, K.; Katsumura, T.; Sallis, J.F. Association of physical activity and neighborhood environment among Japanese adults. Prev. Med. 2009, 48, 321-325. [CrossRef] [PubMed]

5. Kato, H. Effect of Walkability on Urban Sustainability in the Osaka Metropolitan Fringe Area. Sustainability 2020, $12,9248$. [CrossRef]

6. Japanese MILT (Ministry of Land, Infrastructure, Transport and Tourism). Basic Plan on Transport Policy. Available online: https:/ / www.mlit.go.jp/common/001096409.pdf (accessed on 15 September 2020). 
7. Kato, H. Development of a Spatio-temporal Analysis Method to Support the Prevention of COVID-19 Infection: Space-Time Kernel Density Estimation Using GPS Location History Data. In Urban Informatics for Future Cities; Geertman, S., Pettit, C., Goodspeed, R., Staffans, A., Eds.; Springer Nature: Cham, Switzerland, 2021; pp. 51-67. ISBN 978-3-030-76058-8. [CrossRef]

8. Kato, H.; Matsushita, D. Changes in Walkable Streets during the COVID-19 Pandemic in a Suburban City in the Osaka Metropolitan Area. Sustainability 2021, 13, 7442. [CrossRef]

9. Kato, H.; Takizawa, A.; Matsushita, D. Impact of COVID-19 Pandemic on Home Range in a Suburban City in the Osaka Metropolitan Area. Sustainability 2021, 13, 8974. [CrossRef]

10. Kato, H. How Does the Location of Urban Facilities Affect the Forecasted Population Change in the Osaka Metropolitan Fringe Area? Sustainability 2021, 13, 110. [CrossRef]

11. OECD Stat. Metropolitan Areas (Database). Available online: https://stats.oecd.org/Index.aspx?DataSetCode=CITIES (accessed on 16 September 2021).

12. Japanese Law Translation. Local Autonomy Act. Available online: http://www.japaneselawtranslation.go.jp/law/detail/?id=28 $1 \& v m=\& r e=01$ (accessed on 26 July 2021).

13. Renne, J.L.; Tolford, T.; Hamidi, S.; Ewing, R. The Cost and Affordability Paradox of Transit-Oriented Development: A Comparison of Housing and Transportation Costs across Transit-Oriented Development, Hybrid and Transit-Adjacent Development Station Typologies. Hous. Policy Debate 2016, 26, 819-834. [CrossRef]

14. Xia, Z.L.; Li, H.; Chen, Y.H. Assessing Neighborhood Walkability Based on Usage Characteristics of Amenities under Chinese Metropolises Context. Sustainability 2018, 10, 3879. [CrossRef]

15. Zhang, J.; Tan, P.Y.; Zeng, H.; Zhang, Y. Walkability Assessment in a Rapidly Urbanizing City and Its Relationship with Residential Estate Value. Sustainability 2019, 11, 2205. [CrossRef]

16. Boyle, A.; Barrilleaux, C.; Scheller, D. Does Walkability Influence Housing Prices? Soc. Sci. Q. 2014, 95, 852-867. [CrossRef]

17. Li, W.; Joh, K.; Lee, C.; Kim, J.H.; Park, H.; Woo, A. Assessing Benefits of Neighborhood Walkability to Single-Family Property Values: A Spatial Hedonic Study in Austin, Texas. J. Plan. Educ. Res. 2015, 35, 471-488. [CrossRef]

18. Kim, E.J.; Kim, H. Neighborhood Walkability and Housing Prices: A Correlation Study. Sustainability 2020, 12, 593. [CrossRef]

19. Saita, Y.; Shimizu, C.; Watanabe, T. Aging and real estate prices: Evidence from Japanese and US regional data. Int. J. Hous. Mark. Anal. 2016, 9, 66-87. [CrossRef]

20. Maennig, W.; Dust, L. Shrinking and growing metropolitan areas asymmetric real estate price reactions? The case of German single-family houses. Reg. Sci. Urban Econ. 2008, 38, 63-69. [CrossRef]

21. Smith, N.; LeFaivre, M. A class analysis of gentrification. In Gentrification, Displacement, and Neighborhood Revitalization; Palen, J., London, B., Eds.; State University of New York Press: Albany, NY, USA, 1984; pp. 43-63.

22. Kato, H. Residents' evaluations of the tourism gentrification caused by guesthouses in the central area of Kyoto City: A case study of Shutoku District in Kyoto City. IOP Conf. Ser. Mater. Sci. Eng. 2020, 960, 032063. [CrossRef]

23. Paul, K.; Steven, P. Difference and inequality: Socioeconomic and sociocultural patterns. In Urban Social Geography-An Introduction, 6th ed.; Prentice Hall: Harlow, UK, 2010; pp. 67-83.

24. Brownson, R.C.; Hoehner, C.M.; Day, K.; Forsyth, A.; Sallis, J.F. Measuring the built environment for physical activity, state of the science. Am. J. Prev. Med. 2009, 36, 99-123. [CrossRef]

25. Cervero, R.; Kockelman, K. Travel demand and the 3Ds: Density, diversity, and design. Transp. Res. D Transp. Environ. 1997, 2, 199-219. [CrossRef]

26. Duncan, D.T.; Aldstadt, J.; Whalen, J.; Melly, S.J.; Gortmaker, S.L. Validation of Walk Score ${ }^{\circledR}$ for estimating neighborhood walkability: An analysis of four US metropolitan areas. Int. J. Environ. Res. Public Health 2011, 8, 4160-4179. [CrossRef] [PubMed]

27. Frank, L.D.; Schmid, T.L.; Sallis, J.F.; Chapman, J.; Saelens, B.E. Linking objectively measured physical activity with objectively measured urban form. Am. J. Prev. Med. 2005, 28, 117-125. [CrossRef] [PubMed]

28. Frank, L.D.; Sallis, J.F.; Saelens, B.E.; Leary, L.; Cain, K.; Conway, T.L.; Hess, P.M. The development of a walkability index: Application to the neighborhood quality of life study. Br. J. Sports Med. 2009, 44, 924-933. [CrossRef] [PubMed]

29. Owen, N.; Cerin, E.; Leslie, E.; duToit, L.; Coffee, N.; Frank, L.D.; Bauman, A.E.; Hugo, G.; Sealens, B.E.; Sallis, J.F. Neighborhood walkability and the walking behavior of Australian adults. Am. J. Prev. Med. 2007, 33, 387-395. [CrossRef]

30. Koohsari, M.J.; Sugiyama, T.; Hanibuchi, T.; Shibata, A.; Ishii, K.; Liao, Y.; Oka, K. Validity of Walk Score ${ }^{\circledR}$ as a measure of neighborhood walkability in Japan. Prev. Med. Rep. 2018, 9, 114-117. [CrossRef] [PubMed]

31. E-Stat. Japanese Census Data in 2015. Available online: https:/ / www.e-stat.go.jp/ (accessed on 14 June 2020). (In Japanese)

32. Conservation GIS-Consortium Japan. GIS Data. Available online: http:/ /cgisj.jp/download_type_list.php (accessed on 14 April 2020). (In Japanese).

33. Geospatial Information Authority of Japan. The Numerical Map 5000 in Japan. Available online: https://www.gsi.go.jp/ kankyochiri/lum-5k.html (accessed on 1 April 2020). (In Japanese)

34. At Home Co., Ltd. At Home Dataset. Informatics Research Data Repository, National Institute of Informatics (Dataset). 2020. Available online: https://dsc.repo.nii.ac.jp/?action=pages_view_main\&active_action=repository_view_main_item_detail\&item_ id=4333\&item_no=1\&page_id=13\&block_id=21 (accessed on 3 October 2021). [CrossRef]

35. G-Spatial Information Center, Japanese MILT (Ministry of Land, Infrastructure, Transport and Tourism). Future Population and Household Forecast Tool V. 2 (2015 National Census Edition Download Webpage). Available online: https:/ /www.geospatial.jp/ ckan/dataset/ cohort-v2 (accessed on 14 March 2020). 
36. Pivo, G.; Fisher, J.D. The Walkability Premium in Commercial Real Estate Investments. Real Estate Econ. 2011, 39, 185-219. [CrossRef]

37. Lucchesi, S.T.; Larranaga, A.M.; Cybis, H.B.B.; Silva, J.; Arellana, J.A. Are people willing to pay more to live in a walking environment? A multigroup analysis of the impact of walkability on real estate values and their moderation effects in two Global South cities. Res. Transp. Econ. 2021, 86, 14. [CrossRef]

38. Kemeny, J. From Public Housing to the Social Market. In Rental Policy Strategies in Comparative Perspective; Routledge: London, UK, 1995; ISBN 0-415-08365-6.

39. Balletto, G.; Ladu, M.; Milesi, A.; Borruso, G. A Methodological Approach on Disused Public Properties in the 15-Minute City Perspective. Sustainability 2021, 13, 593. [CrossRef]

40. Osaka City. Midosuji Future Vision (Summary Version). Available online: https://www.city.osaka.lg.jp/kensetsu/cmsfiles/ contents/0000464/464479/gaiyou.pdf (accessed on 31 July 2021). (In Japanese).

41. Kyoto City. Kyoto City Urban Planning Master Plan (Draft). Available online: https://www.city.kyoto.lg.jp/templates/ pubcomment/cmsfiles/contents/0000285/285150/toshimasu_soan.pdf (accessed on 31 July 2021). (In Japanese).

42. Ministry of Land, Infrastructure, Transport and Tourism of Japan. National Land Information Download Service. Available online: http:/ /nlftp.mlit.go.jp/ksj/index.html (accessed on 14 March 2020). 